Article

\title{
Determining Regional Actual Evapotranspiration of Irrigated Crops and Natural Vegetation in the São Francisco River Basin (Brazil) Using Remote Sensing and Penman-Monteith Equation
}

\author{
Antônio H. de C. Teixeira \\ Embrapa Semiárido, P.O. Box 23, 56302-970, Petrolina, PE, Brazil; \\ E-Mail: heribert@cpatsa.embrapa.br; Tel.: +55-87-3862-1711; Fax: +55-87-3862-1744
}

Received: 3 February 2010; in revised form: 29 March 2010 / Accepted: 14 April 2010 /

Published: 6 May 2010

\begin{abstract}
To achieve sustainable development and to ensure water availability in hydrological basins, water managers need tools to determine the actual evapotranspiration (ET) on a large scale. Field energy balances from irrigated and natural ecosystems together with a net of agro-meteorological stations were used to develop two models for ET quantification at basin scale, based on the Penman-Monteith equation. The first model (PM1) uses the resistances to the latent heat fluxes estimated from satellite measurements, while the second one (PM2) is based on the ratio of ET to the reference evapotranspiration $\left(\mathrm{ET}_{0}\right)$ and its relation to remote sensing parameters. The models were applied in the Low-Middle São Francisco river basin in Brazil and, after comparison against field results, showed good agreements with PM1 and PM2 explaining, respectively, 79\% and 89\% of the variances and mean square errors (RMSE) of 0.44 and $0.34 \mathrm{~mm} \mathrm{~d}^{-1}$. Even though the PM1 model was not chosen for ET calculations, the equation for surface resistance $\left(r_{s}\right)$ was applied to infer the soil moisture conditions in a simplified vegetation classification. The maximum values of $r_{s}$ were for natural vegetation - caatinga (average of 1,937 $\mathrm{s} \mathrm{m}^{-1}$ ). Wine grape and mango orchard presented similar values around $130 \mathrm{~s} \mathrm{~m}^{-1}$, while table grape presented the lowest ones, averaging $74 \mathrm{~s} \mathrm{~m}^{-1}$. Petrolina and Juazeiro, in Pernambuco (PE) and Bahia (BA) states, respectively, were highlighted with the biggest irrigated areas. The highest increments are for vineyards and mango orchards. For the first crop the maximum increment was verified between 2003 and 2004 in Petrolina-PE, when the cultivated area increased $151 \%$. In the case of mango orchards the most significant period was from 2005 to 2006 in Juazeiro-BA (129\%). As the best performance was for PM2, it was selected and used to analyse the regional ET at daily and annual scales, making use of Landsat images and a geographic information system for different soil
\end{abstract}


moisture conditions. Considering the daily rates of the regional ET, pixels with values lower than $1.0 \mathrm{~mm} \mathrm{~d}^{-1}$ occurred outside the rainy season, representing the caatinga species. Values from 1.0 to $5.0 \mathrm{~mm} \mathrm{~d}^{-1}$ during the driest conditions of the year coincided with irrigated crops, being the highest values for table grapes. The highest accumulated ET values during 2006 were for mango orchards, being around 500-1,300 $\mathrm{mm} \mathrm{yr}^{-1}$. Vineyards presented lower values, ranging from $450-800 \mathrm{~mm} \mathrm{yr}^{-1}$, while in caatinga they were between 200 and $400 \mathrm{~mm} \mathrm{yr}^{-1}$. It could be concluded that irrigated mango orchards and vineyards in that year consumed more water than caatinga by factors of 3 and 2 , respectively. The mango orchards and vineyard areas, representing 19.4 and $8.2 \%$ of the total irrigated area, respectively, resulting in a total evaporative depletion of $0.22 \mathrm{~km}^{3} \mathrm{yr}^{-1}$ in the growing regions comprised of the agro-meteorological stations.

Keywords: energy balance; modeling; latent heat flux; water management; satellite measurements

\section{Introduction}

Disputes over shared water resources are raising local, national, and even international tensions. Rising conflicts are expected as populations expand, economies grow, and the competition for limited water supplies intensifies [1]. Basin-level dialogs among different users to negotiate and agree on the allocation of water resources are required. The success of any dialog depends on the knowledge base and the general trust in data sources, such as the actual evapotranspiration (ET) of each land use type. Experimentally, the calculation of ET can be made accurately using the Bowen ratio (BR) method, eddy covariance (EC) techniques, and scintillometers. The BR method has been applied in agricultural crops and natural vegetation [2-5]. Examples of EC measurements can also be found [6-14]. However, the spatial variability is significant and extrapolation of energy balance data directly from flux tower to a surrounding landscape environment can lead to inaccurate regional estimates. Aiming to increase the spatial scales, ET was obtained by means of scintillometers across a path length of several kilometers [15,16], but these field methods cannot provide a fair sample of a whole biome [17]. Remote sensing, excluding the need of quantifying other complex hydrological processes, is an excellent means for determining and mapping the spatial and temporal structure of the energy balance components, including ET, at basin scale.

Vegetative indexes remotely obtained, together with agro-meteorological data, can be used to extrapolate ET values from local to regional scales. Hydrological models are in general too complex and costly for this extrapolation because of the difficulty in obtaining data sets in different hydrological uniform sub-areas and due to this deficiency, these models can yield unreliable results [18]. Oversimplification of land surface complexity may cause hydrological models to be biased and if species-specific algorithms were needed to scale tower data to larger areas, detailed, species-level vegetation maps of each river stretch would be necessary [19]. With the technological advances in satellites, electronic equipment and informatics in the 21 st century, several remote sensing methods for 
regional ET calculations have been reviewed and improved [20-28]. Research on obtaining crop coefficients for applications in water management have also been carried out [29-37].

Several remote sensing algorithms have been developed. The energy balance methods have several advantages. The Surface Energy Balance Algorithm for Land-SEBAL [38], the Surface Energy Balance Index-S-SEBI [39] and the Surface Energy Balance System-SEBS [40], taking into account the crop conditions can be applied to various ecosystems without the need of crop classification. The identification of fruit trees from satellite data is not straightforward [41]. Unresolved problems for identifying different fruit crops in the semi-arid region of the São Francisco river basin in Brazil were reported [42]. It is considered easier to determine ET based on thermal infrared imagery, rather than through the procedures of crop classification [43]. However, the disadvantage of the energy balance methods is the need to identify extreme conditions, which is not required for the Two-Source Model-TSM [44], Dual-Temperature Difference-DTD [45] and Disaggregated Atmosphere Land Exchange Inverse model-DisALEXI [46]. The aerodynamic resistance-surface energy balance approach-RSEB [47] failed because small errors in the radiative temperature translate into large errors in the sensible heat fluxes, and then into estimates of ET.

One of the problems in relation to the applicability of the energy balance models, aimed at the end users, is the need of background knowledge in radiation physics involved inside these algorithms. The suitability of applying the Penman-Monteith (PM) equation by the surface conductance algorithm has been shown by using remotely-sensed vegetation indices (leaf area index and NDVI) together with weather data [23]. The big advantages of the PM equation are the applicability and the low sensitivity to input data and parameters. Its use is also highlighted by the METRIC model, which applies the reference evapotranspiration $\left(\mathrm{ET}_{0}\right)$ throughout the ratio $\mathrm{ET} / \mathrm{ET}_{0}$ to extrapolate instantaneous values of ET to larger time scales [48].

ET remote sensing methods have been useful for studies that were carried out involving net depletion of river flows, administering water rights, crop water requirements and irrigation management in the Western US states [49]. The effectiveness of using very high resolution visible and thermal infrared images in an Israeli vineyard for scheduling irrigation was demonstrated [50]. Thermal infrared measurements have enabled growers to produce maps of relative water stress in orchards [51]. With the use of ET and biomass production maps, crop water productivity was analyzed in the semi-arid conditions of Brazil [37]. However, the remote surface temperature and vegetation cover must be at high enough resolutions, where different land surface conditions can be distinguished, important for the validation of ET estimated by land surface models [52]. Procedures for the validation of remote sensing models have been carried out [53-60]. The research primarily involved comparing energy balance measurements from satellites with those of tower-based systems. Data from flux stations increase the confidence in remote sensing techniques, however, the success of the applicability of satellite images in quantifying water consumption is conditioned by the availability of biophysically realistic models, which are simple enough for implementation [23].

The intensification of agriculture in the Low-Middle São Francisco river basin, Brazil, with mainly fruit crops, has caused large land use changes, with the replacement of the natural vegetation (caatinga) by large irrigated areas. Water scarcity in some areas and periods of the year has been a problem and the drainage of irrigated agriculture may affect the water quality. With the reduction of the amount of good quality water, conflicts among users tend to rise. To avoid both water scarcity and water excess, 
one must have efficient tools to quantify ET at the basin scale. Field energy balance measurements in this region have been done in vineyards [5], mango orchard [13] and natural vegetation [14]; however, the results from these specific flux towers are only first estimations of ET in a region containing different ecosystems.

The energy balance methods using satellite measurements have the advantage that, while taking into account the crop growing conditions, they do not require a crop classification. However, for some of them, identification of extreme conditions is necessary [38-40] which can be difficult during the rainy seasons. The SEBAL algorithm was calibrated and validated with field measurements in surfaces with hydrological contrast in the semi-arid region of the São Francisco river basin [27]. Although the model performed well, the difficulty lies in its assumption of zero ET for dry pixels, which is difficult during the rainy season, because the regional moisture status is homogeneous in the mixed ecosystems of irrigated crops and natural vegetation.

Considering the simplicity of application, and its needing neither crop classification nor extreme conditions, two models based on the PM equation were developed and validated with field data from four flux stations involving irrigated crops and natural vegetation, in the semi-arid conditions of the Low-Middle São Francisco river basin $[5,13,14]$. The modeling involved the net radiation and soil heat fluxes, the resistances to water fluxes, and interpolated weather data. Remote sensing parameters from Landsat images, together with field energy balance experiments and a net of agro-meteorological stations were used. The two simple observation models, when used with satellites and a net of agro-meteorological stations, will be appropriate for implementation at basin scale for ET monitoring. After validation, a first application of the one selected was done for regional and incremental ET analyses at daily and annual scales, which are useful for decision-making policies in conditions of quick land and water use changes.

\section{Material and Methods}

\subsection{Modeling Evapotranspiration}

\subsubsection{General Equations}

The physical process, whereby water flows from evaporating surfaces into the atmosphere, is referred to as actual evapotranspiration (ET). This water flux occurs via canopies through stomata as actual transpiration and directly from the soil surface as actual evaporation. Stomata are small openings on the plant leaf through which gases and water vapor pass. The vaporization occurs within the leaf, in the intercellular spaces, and the vapor exchange with the atmosphere is controlled by the stomatal aperture, which can be open and closed, depending on the pressure of the guard cell. Nearly all soil water taken up by roots is lost by transpiration and a negligible fraction is used within the plant. Not only the type of crop, but also the crop development, environment, cultural management and irrigation system should be considered when assessing transpiration.

For modeling ET, distinctions are made between reference crop evapotranspiration $\left(\mathrm{ET}_{0}\right)$ and actual evapotranspiration (ET). $\mathrm{ET}_{0}$ is the evapotranspiration rate from a reference surface, not short of water, which can be a hypothetical grass surface with specific characteristics, while ET involves all conditions of any vegetated surface. Agro-meteorological parameters, vegetation characteristics, 
management and environmental aspects affect ET. Other factors to be considered are ground cover, plant density, plant architecture, microclimate and soil moisture. Considering irrigated crops, cultivation practices and the type of irrigation system, can alter the microclimate, affecting the canopy characteristics and the moisture content of the soil and the plants. The effect of soil moisture on water fluxes is primarily conditioned by the magnitude of the water deficit and the type of soil. On the other hand, too much water will result in water logging, which might damage the root and limit root water uptake by inhibiting respiration [61].

Evapotranspiration is an energy consuming process, referred to as the latent heat flux $(\lambda \mathrm{E})$. ET can be derived from the latent heat of vaporization $(\lambda)$, density of water and $\lambda \mathrm{E}$. As a first approximation, an ET of $1 \mathrm{~mm} \mathrm{~d}^{-1}$ is equivalent to a $\lambda \mathrm{E}$ of $28 \mathrm{~W} \mathrm{~m}^{-2}$, being therefore the chain between the water and energy balances. All energy fluxes should be considered when deriving the energy balance equation, which for a given surface can be written as:

$$
R_{n}-\lambda E-H-G=0
$$

where $R_{n}$ is the net radiation, $H$ is the sensible heat flux and $G$ is the soil heat flux. All terms in Equation 1 can be expressed in $\mathrm{W} \mathrm{m}^{-2}$ or $\mathrm{MJ} \mathrm{m}^{-2} \mathrm{~d}^{-1}$, being either positive or negative. Positive $\mathrm{R}_{\mathrm{n}}$ means energy flux to the surface and positive $\mathrm{G}, \lambda \mathrm{E}$ and $\mathrm{H}$ indicate fluxes of energy from the surface. Equation 1 states that the $R_{n}$ is redistributed over $H, \lambda E$ and $G$, considering only vertical fluxes and ignoring the net rate at which energy is being transferred horizontally, by advection; however, this term can be significant near the edges of crops or natural vegetation [62]. Therefore it is accurate only when applied to large, extensive surfaces. Other energy terms, such as heat stored or released in the canopies, or the energy used in metabolic activities, are not considered. These last terms account only for a small fraction of the daily $\mathrm{R}_{\mathrm{n}}$ and can be neglected in hydrological studies.

The atmosphere warms up when $\mathrm{R}_{\mathrm{n}}$ is positive. Heating of the atmosphere occurs from the land surface, thus the surface temperature $\left(T_{0}\right)$ during daylight hours exceeds the air temperature $\left(T_{a}\right) . H$ is the rate of heat loss to the air by convection and conduction, due to a temperature difference, being expressed by the following equation for heat transport [63]:

$$
H=\frac{\rho_{a} C_{p}\left(T_{0}-T_{a}\right)}{r_{a h}}
$$

where $\rho_{\mathrm{a}}$ is air density $\left(\mathrm{kg} \mathrm{m}^{-3}\right), \mathrm{c}_{\mathrm{p}}$ is air specific heat at constant pressure $\left(\mathrm{J} \mathrm{kg}^{-1} \mathrm{~K}^{-1}\right), \mathrm{T}_{0}$ and $\mathrm{T}_{\mathrm{a}}$ are in $\mathrm{K}$; and $\mathrm{r}_{\mathrm{ah}}$ is the aerodynamic resistance to heat transport in the boundary above the land surface $\left(\mathrm{s} \mathrm{m}^{-1}\right)$ applicable to the same two heights.

$\lambda \mathrm{E}$ can be determined as:

$$
\lambda E=\frac{\rho_{\mathrm{a}} \mathrm{c}_{\mathrm{p}}}{\gamma}\left[\frac{\mathrm{e}_{\mathrm{s}}\left(\mathrm{T}_{0}\right)-\mathrm{e}_{\mathrm{a}}}{\mathrm{r}_{\mathrm{av}}+\mathrm{r}_{\mathrm{s}}}\right]
$$

where $\gamma$ is the psychrometric constant $\left(\mathrm{kPa}^{\circ} \mathrm{C}^{-1}\right)$; $\mathrm{e}_{\mathrm{a}}$ is the actual water vapor pressure of the air $(\mathrm{kPa})$ at the reference height above the surface $(\mathrm{z}) ; \mathrm{r}_{\mathrm{s}}$ and $\mathrm{r}_{\mathrm{av}}$ are respectively the surface and aerodynamic resistances $\left(\mathrm{s} \mathrm{m}^{-1}\right)$ to the latent heat flux; and $\mathrm{e}_{\mathrm{s}}\left(\mathrm{T}_{0}\right)$ is the saturated water vapor pressure $(\mathrm{kPa})$ at $\mathrm{T}_{0}$.

These fundamental equations constitute the base for regional ET modeling approaches, which use remotely-sensed radiances. The transfer equations for $\mathrm{H}$ (Equation 2) and for $\lambda \mathrm{E}$ (Equation 3) were combined [64] into the surface energy balance (Equation 1), and the world wide accepted combination 
equation for open water evaporation was developed. The combination equation was modified into a version that can be applied to the vegetated surfaces by inserting a canopy resistance [65], eliminating $\mathrm{T}_{0}$ from Equations 1-3.

Considering $r_{a h}$ and $r_{a v}$ nearly equal in practice, and replaced by $r_{a}$ for both heat and vapor flux transports, the PM equation to predict ET from vegetated surfaces [61] became:

$$
\lambda E=\frac{\Delta\left(R_{n}-G\right)+\rho_{a} c_{p} D / r_{a}}{\Delta+\gamma\left(1+r_{s} / r_{a}\right)}
$$

where $\Delta\left(\mathrm{kPa}^{\circ} \mathrm{C}^{-1}\right)$ is the slope of the saturated vapor pressure curve and $\mathrm{D}(\mathrm{kPa})$ is the vapor pressure deficit in the air near the vegetated surfaces.

The difficulties of using Equation 4, especially at the regional scale, are considered to be the estimations of $r_{a}$ and $r_{s}$ [66]. Differences in crop height and leaf area index (LAI) determine crop roughness and thereby $r_{a}$. Crop rooting characteristics, root water uptake and LAI influence the value of $r_{s}$. With the availability of the evapotranspiration resistances, ET can be derived from agrometeorological data by means of Equation 4, providing a good approach because it combines the main drivers of water fluxes; provides an energy constraint on the water fluxes; and modeled ET are not overly sensitive to any of the inputs [23]. The magnitude of $r_{s}$ is mainly governed by environmental entities and soil moisture status [67,68]. Where the vegetation does not completely cover the soil, $\mathrm{r}_{\mathrm{s}}$ includes the effects of the soil evaporation. With field values of $\lambda E, R_{n}, G, r_{a}$ and microclimatic data, $r_{s}$ can be estimated inverting Equation $4[5,13,14]$, and together with remote sensing parameters, the ET at the regional scale can be obtained. On the other hand, Equation 4 applied to the reference crop allows the modeling of the ratio $\mathrm{ET} / \mathrm{ET}_{0}$ with satellite variables. The next section describes the steps for modeling by using the PM equation in these two ways.

\subsubsection{Penman-Monteith models}

Table 1 summarizes the steps for modeling the regional ET by the two models based on the PM equation. For the first model (PM1), the radiation balance was done with locally calibrated equations and satellite values of $R_{n}, G$ and the evapotranspiration resistances together with weather data, while for the second one (PM2), the only remote sensing parameters are the surface albedo $\left(\alpha_{0}\right)$, the surface temperature $\left(\mathrm{T}_{0}\right)$ and the Normalized Difference Vegetation Index (NDVI). For both models, the ratio $\mathrm{ET} / \mathrm{ET}_{0}$ is applied to grids of $\mathrm{ET}_{0}$ at instantaneous and daily time scales.

Table 1. Summary of the regression analyses.

\begin{tabular}{lllll}
\hline Parameter & Equation & a & b & $\mathbf{R}^{2}$ \\
\hline$\alpha_{0}$ & $\alpha_{0}=\mathrm{a} \alpha_{\mathrm{p}}+\mathrm{b}$ & 0.70 & 0.06 & 0.96 \\
$\mathrm{~T}_{0}$ & $\mathrm{~T}_{0=} \mathrm{aT}$ sat $+\mathrm{b}$ & 1.11 & -31.89 & 0.95 \\
$\varepsilon_{\mathrm{a}}$ & $\varepsilon_{\mathrm{a}}=\mathrm{a}\left(-\mathrm{ln}_{\mathrm{sw}}\right)^{\mathrm{b}}$ & 0.94 & 0.10 & 0.75 \\
$\varepsilon_{0}$ & $\varepsilon_{0}=\mathrm{a} \operatorname{lnNDVI}+\mathrm{b}$ & 0.06 & 1.00 & 0.90 \\
$\mathrm{G} / \mathrm{R}_{\mathrm{n}}$ & $\mathrm{G} / \mathrm{R}_{\mathrm{n}}=\mathrm{a} \exp \left(\mathrm{b} \alpha_{0}\right)$ & 3.98 & -25.47 & 0.90 \\
$\mathrm{z}_{0 \mathrm{~m}}$ & $\mathrm{z}_{0 \mathrm{~m}}=\exp \left[\left(\mathrm{aNDVI} / \alpha_{0}\right)+\mathrm{b}\right]$ & 0.24 & -2.12 & 0.92 \\
$\mathrm{r}_{\mathrm{s}}$ & $\mathrm{r}_{\mathrm{s}}=\exp \left[\mathrm{a}\left(\mathrm{T}_{0} / \alpha_{0}\right)(1-\mathrm{NDVI})+\mathrm{b}\right]$ & 0.04 & 2.72 & 0.93 \\
$\mathrm{r}_{\mathrm{a}}$ & $\mathrm{r}_{\mathrm{a}}=\mathrm{az}_{\mathrm{oh}}{ }^{1}+\mathrm{b}$ & 0.22 & 29.5 & 0.78 \\
$\mathrm{ET} / \mathrm{ET}_{0}$ & $\mathrm{ET} / \mathrm{ET}_{0}=\exp \left\{\mathrm{a}+\mathrm{b}\left[\mathrm{T}_{0} /\left(\alpha_{0} \mathrm{NDVI}\right)\right]\right\}$ & 1.90 & -0.008 & 0.91 \\
\hline
\end{tabular}


Figure 1 shows the radiation balance for obtaining $R_{n}$ with the parameterizations of Table 1 , necessary for the PM1 model.

Figure 1. Schematic flowchart for the regional radiation balance for PM1 model.

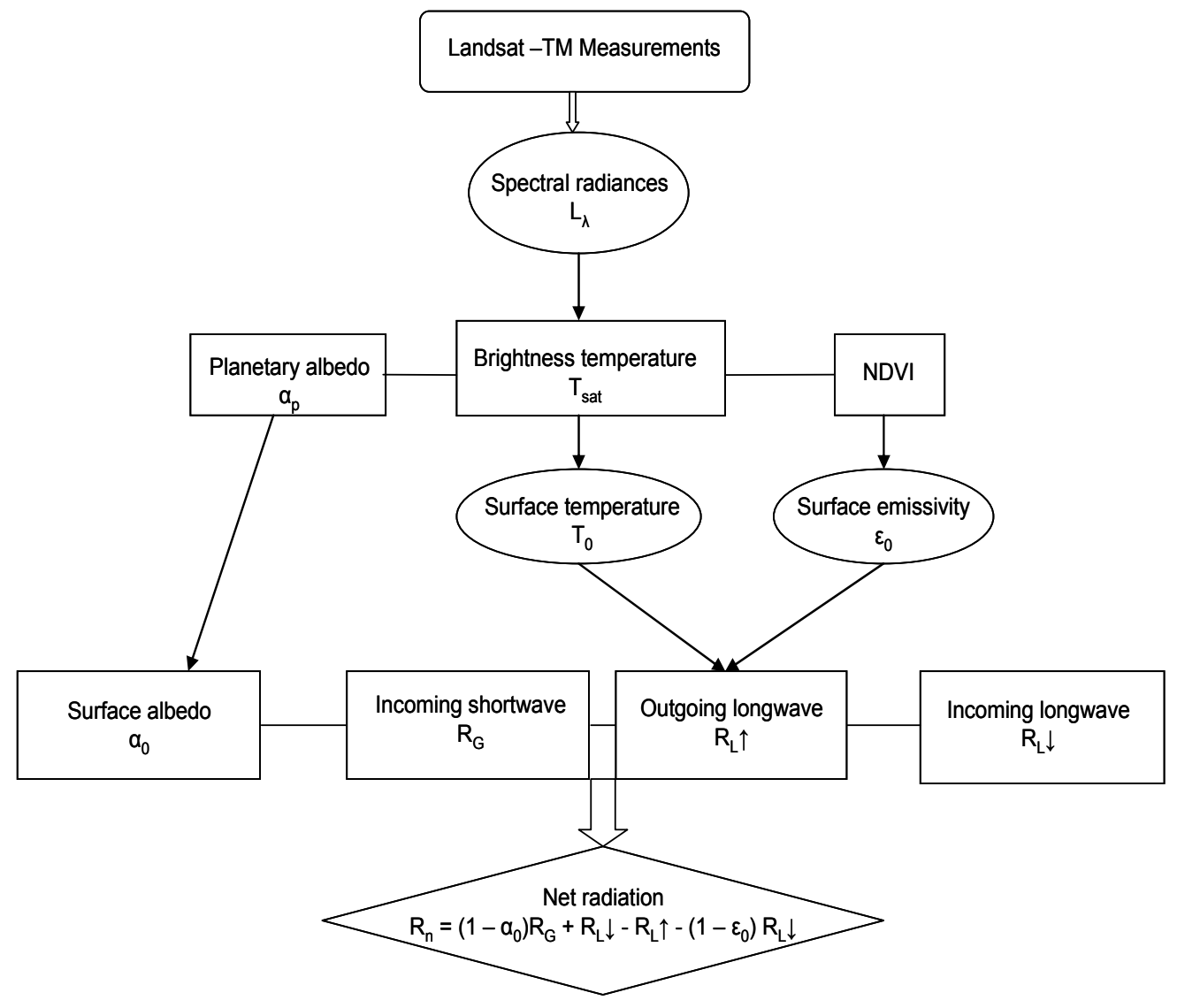

Simple regression equations were used for atmospheric correction to obtain the regional values of $\alpha_{0}$ and $T_{0}$ by using field and satellite measurements. The satellite measured radiances are affected by the atmospheric interaction in the radiative transfer path, being part of the incident global solar radiation $\left(\mathrm{R}_{\mathrm{G}}\right)$ scattered back before it reaches the earth surface. A simplified linear relationship between $\alpha_{0}$ measured by pyranometers in the field and the planetary albedo by Landsat satellite $\left(\alpha_{p}\right)$ has been applied [69]. From the field energy balance experiments, the aerodynamic surface temperature $\left(\mathrm{T}_{0}\right)$ was calculated from Equation 2 while the radiometric surface temperature was obtained from the Landsat band $6\left(\mathrm{~T}_{\text {sat }}\right)$. Other than for a thin surface, a difference arises between radiometric and aerodynamic surface temperatures [70]. Excellent agreement was found between aerodynamic surface and canopy radiometric temperatures for a dense, fully closed wheat crop [71], however, for sparse or composite vegetation, the differences increase [72]. The satellite thermal radiation was therefore corrected for both atmospheric emission and the difference between radiometric and surface temperature by applying a regression equation with field and satellite values (Table 1).

Considering that the field measurements involved contrasting hydrological surfaces with different values for $\alpha_{0}$; for the use of the Equation 2 for estimating $T_{0}$, microclimatic measurements with stability corrections were applied to $r_{a}$ in flux profile relationships. Since EC systems directly provide $\mathrm{u} *$, with good agreements of $\mathrm{H}$ when comparing field and satellite values [27], it is assumed that the 
two key first regressions from Table 1 have good accuracy in the semi-arid region of the Low-Middle São Francisco river basin.

In the regional radiation balance (Figure 1), the net short wave radiation available at the earth surface depends on $\mathrm{R}_{\mathrm{G}}$ and $\alpha_{0}$.

Measured $\mathrm{R}_{\mathrm{L}} \downarrow$ over natural vegetation (caatinga) — in combination with microclimatic data of air temperature $\left(\mathrm{T}_{\mathrm{a}}\right)$ - accorded the inspection of the apparent emissivity of the atmosphere $\left(\varepsilon_{\mathrm{a}}\right)$. The regional values of $R_{L} \downarrow$ were then estimated from the Stefan Boltzman equation by using the relation of $\varepsilon_{\mathrm{a}}$ with the atmospheric transmissivity $\left(\tau_{\mathrm{sw}}\right)$ together with grids of $\mathrm{T}_{\mathrm{a}}$ from the net of agro-meteorological stations. $\tau_{\mathrm{sw}}$ was, in turn, calculated by the ratio of the grid of $\mathrm{R}_{\mathrm{G}}$ measured by the net of pyrometers and the solar radiation at the top of the atmosphere $\left(R_{a}\right)$ [27]. For $R_{L} \uparrow$, the Stefan Boltzman equation was applied using images of $T_{0}$ and the correlation of field values of surface emissivity $\left(\varepsilon_{0}\right)$ and satellite measurements of NDVI [73], this last parameter being obtained from the infrared and red regions of the Landsat images.

The regional values of $R_{n}$ resulted from the balance of all short and long wave radiations (Figure 1). The term $G$ in large scale was acquired by an exponential relation of field values of the ratio $G / R_{n}$ and $\alpha_{0}$, assuming that both ratios are dependent on the type and architecture of the vegetation and soil moisture conditions and that the exponential relation was the best found for comparing the two ratios involving natural vegetation and irrigated crops $\left(\mathrm{R}^{2}=0.96\right)$ under several hydrological conditions in semi-arid region of Brazil (Table 1).

The behavior of $\mathrm{z}_{0 \mathrm{~m}}$ in natural vegetation and irrigated crops was described for the semi-arid conditions of the Low-Middle São Francisco river basin [14]. To estimate this roughness parameter at the regional scale from remote sensing measurements, a simplified expression based on $\alpha_{0}$ from field measurements and NDVI from satellite images, with locally calibrated regression coefficients shown in Table 1 was used. The inclusion of $\alpha_{0}$ helps to distinguish between vegetation having different architecture but similar values of NDVI [48]. For example table grape may present the same NDVI values as mango orchard, but substantially lower LAI. The coefficient of determination is rather encouraging for describing a difficult land surface parameter by some simplified remote sensing variables.

For the PM1 model, $\mathrm{r}_{\mathrm{a}}$ was estimated from the roughness length for heat transport $\left(\mathrm{z}_{0 \mathrm{~h}}\right)$, which in turn was considered as a function of $\mathrm{z}_{0 \mathrm{~m}}\left(\mathrm{z}_{0 \mathrm{~h}}=0.1 \mathrm{z}_{0 \mathrm{~m}}\right)$ [61]. This relation is very useful, as there is no unique relationship between surface roughness characteristics such as the geometry of the roughness elements and $z_{0 h}[74,75]$. The low determination coefficient in Table 1 is not a problem, because Equation 4 is insensitive to $r_{a}$, especially when $r_{a}<<r_{s}$ and at daily timescales [23]. Finally, to complete the resistance terms in the PM equation, the field values of $r_{s}$ were correlated with the field values of $T_{0}, \alpha_{0}$ and satellite measurements of NDVI. For PM2 model, the instantaneous ET/ET ${ }_{0}$ field values were also modeled with field values of $T_{0}$ and $\alpha_{0}$ together with satellite data of NDVI (Table 1).

Figure 2 presents the schematic overview to convert spectral radiance into ET by using the satellite parameters and the grids of daily $\mathrm{ET}_{0}$ when applying the PM2 model. 
Figure 2. Schematic flowchart for calculating the actual evapotranspiration when applying the PM2 model.

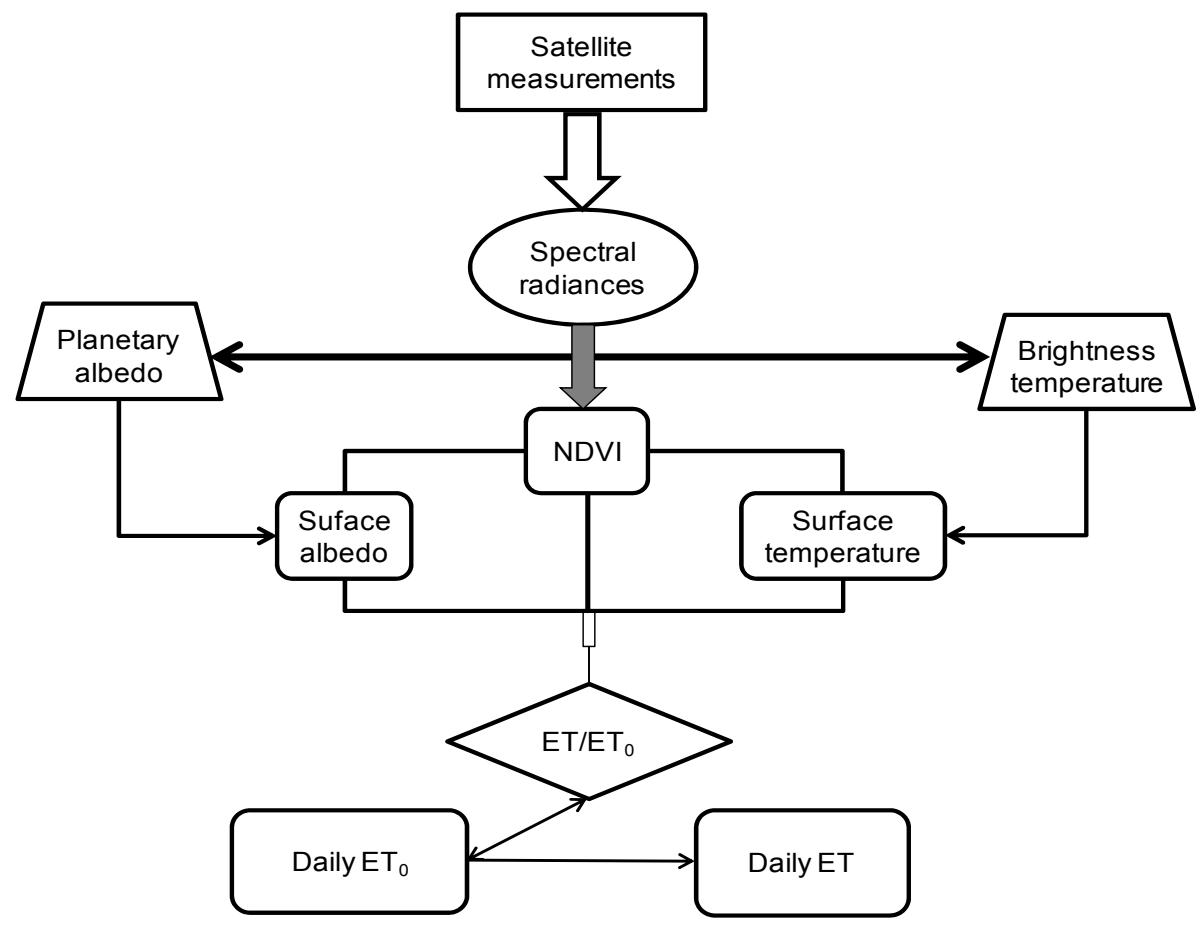

After converting the spectral radiances and the atmospheric corrections, the images of NDVI, $\alpha_{0}$ and $\mathrm{T}_{0}$ are the only input parameters for estimating the instantaneous values of the ratio $\mathrm{ET} / \mathrm{ET}_{0}$ without the need of the regional radiation balance shown in Figure 1. The instantaneous values of this ratio are multiplied by the daily grids of $\mathrm{ET}_{0}$ to estimate the regional ET for 24 hours.

Both, $\mathrm{r}_{\mathrm{s}}$ and $\mathrm{ET} / \mathrm{ET}_{0}$ values are related to the soil moisture conditions and so are the remote sensing vegetation indicators such as NDVI, $\alpha_{0}$ and $\mathrm{T}_{0}$. Based on this principle, two models were proposed. The relationship between vegetation indices with soil moisture and ET rates have been reported in the semi-arid region of Brazil [14,27]. The relations for modeling the regional ET in a mixture of natural vegetation and irrigated crops are depicted in Figure 3.

For the first model based on direct application of Equation 4 (PM1), the images of $R_{n}, G, r_{s}$ and $r_{a}$, are used together with the interpolated weather data from the net of agro-meteorological stations (Table 1; Figures 1, $3 \mathrm{a}$ and $3 \mathrm{~b}$ ). The regional values of $\lambda \mathrm{E}$ are acquired and transformed into millimeters of water (ET). After the determination of ET at the regional scale, the instantaneous ratio of $\mathrm{ET} / \mathrm{ET}_{0}$ is calculated with grids of $\mathrm{ET}_{0}$ for these same spatial and time scales. The second model (PM2) is based on the modeling of $\mathrm{ET} / \mathrm{ET}_{0}$ at the satellite overpass time (subscript sat) at the regional scale (Table 1 and Figure 3c). The instantaneous images of ET/ET ${ }_{0}$ obtained by both models are then multiplied by the grids of $\mathrm{ET}_{0}$ for 24 hours.

The satellite overpass time values of ET/ET $\mathrm{ET}_{0}$ and those for 24 hours in irrigated mango orchard and caatinga were compared (Figure 3d). The slope is close to one, supporting the assumption that instantaneous and daily ratios can be considered equal. A factor of 1.18 for the evaporative fraction $\left[E F=\lambda E /\left(R_{n}-G\right)\right]$ was necessary to extrapolate the latent heat fluxes from satellite overpass to daily time scale based on field and satellite measurements in the semi-arid conditions of the Low-Middle São Francisco river basin, Brazil [14,37]. 
Figure 3. Relations for the evapotranspiration resistances and ET/ET 0 ratio. (a) Surface resistance $\left(r_{s}\right)$; (b) aerodynamic resistance $\left(r_{a}\right) ;(\mathbf{c})$ satellite overpass time value of ET/ET 0 (subscript sat). (d) daily values of $\mathrm{ET} / \mathrm{ET}_{0}$ (subscript 24). $\mathrm{T}_{0}$ : surface temperature; $\alpha_{0}$ : surface albedo; NDVI: Normalized Difference Vegetation Index; $\mathrm{z}_{0 \mathrm{~h}}$ : roughness length for heat transport.
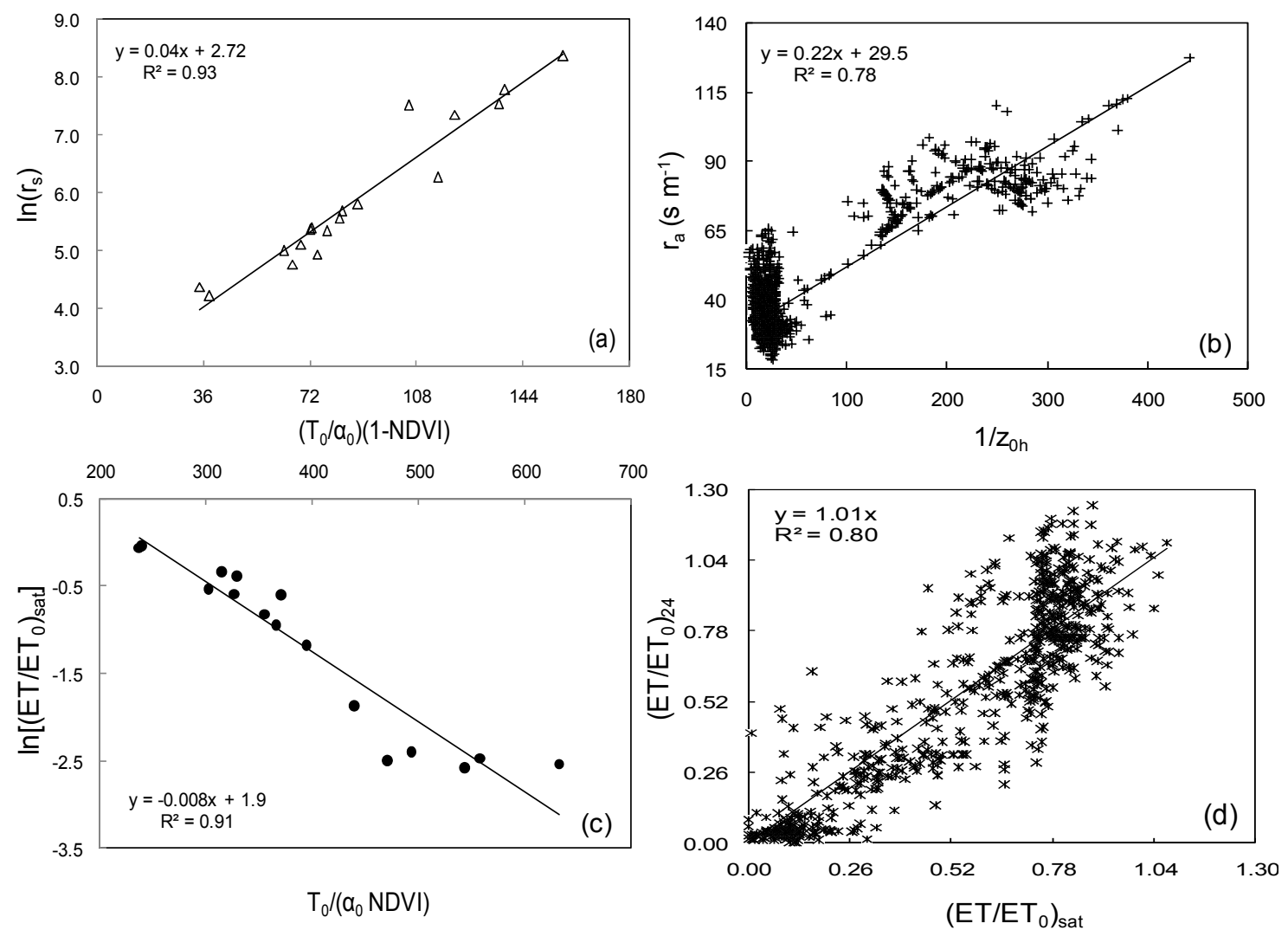

The coefficients of determination in Figures $3 a$ and $3 c$ are very good $\left(R^{2}>0.90\right)$. The lower value for $r_{a}$ (Figure $3 b$ ) is not a big problem since, according to some sensitivity analysis errors in $\lambda E$ estimations, changes in the magnitudes of this resistance do not cause large errors, because it appears in both the numerator and the denominator of the PM equation $[23,76]$.

\subsection{Field and Remote Sensing Parameterizations}

\subsubsection{Field Parameters}

The transfer of heat and water vapor from the evaporating surface into the air above the canopy is determined by $r_{a}$, which was estimated using flux profile relationships (FP) in vineyards and EC measurements in mango orchard and natural vegetation. The atmospheric surface-layer similarity theory was applied in both situations to estimate the roughness elements related to mechanically generated turbulence. The universal functions and the integrated stability functions of temperature $\left(\Psi_{\mathrm{h}}\right)$ and momentum $\left(\Psi_{\mathrm{m}}\right)$ were applied [77]. This resistance accounts for the drag force between land and atmosphere in Equation 4. Its determination requires the surface roughness for heat transfer $\left(\mathrm{z}_{0 \mathrm{~h}}\right)$ and friction velocity $(\mathrm{u} *)$ to be specified: 


$$
r_{a}=\frac{\ln \left[\frac{\mathrm{z}-\mathrm{d}}{\mathrm{z}_{0 \mathrm{~h}}}\right]-\psi_{\mathrm{h}}\left(\frac{\mathrm{z}-\mathrm{d}}{\mathrm{L}}\right)}{\mathrm{ku}_{*}}
$$

where $\mathrm{z}(\mathrm{m})$ is the measurement height, $\mathrm{d}(\mathrm{m})$ is the displacement height, $\mathrm{k}$ is the von Karman's constant $(0.41), \psi_{\mathrm{h}}$ is the stability correction due to buoyancy and $\mathrm{L}$ is the Obukhov length.

For vineyards $\mathrm{u} *$ was calculated by using two levels of wind speed measurements [5], while for mango orchard and caatinga the EC measurements directly provided this roughness parameter $[13,14]$. The value for $\mathrm{z}_{0 \mathrm{~h}}$ was then considered to be $10 \%$ of the roughness length for moment transfer $\left(\mathrm{z}_{0 \mathrm{~m}}\right)$.

With field measurements of wind speed over the vegetation the $\mathrm{z}_{0 \mathrm{~m}}$ was obtained by:

$$
\mathrm{z}_{0 \mathrm{~m}}=\frac{\mathrm{z}-\mathrm{d}}{\exp \left(\frac{\mathrm{ku}(\mathrm{z})}{\mathrm{u}_{*}}+\Psi_{\mathrm{m}}\left(\frac{\mathrm{z}-\mathrm{d}}{\mathrm{L}}\right)\right)}
$$

where $\mathrm{u}(\mathrm{z})$ is the wind speed at the first level $\left(\mathrm{z}=\mathrm{z}_{1}\right)$ in vineyards or at the height of the sonic anemometer above mango orchard or caatinga and $\psi_{\mathrm{m}}$ is the stability function for momentum.

Microclimatic data of air temperature $\left(T_{a}\right)$ and relative humidity $(R H)$ were used together with $R_{n}$, $\lambda \mathrm{E}$ and $\mathrm{G}$ to estimate $\mathrm{r}_{\mathrm{s}}$ inverting Equation 4.

The aerodynamic temperature $\left(\mathrm{T}_{0}\right)$ was calculated from Equation $2[27,63]$ with field data of $r_{a}, T_{a}$ and $\mathrm{H}$ :

$$
\mathrm{T}_{0}=\mathrm{T}_{\mathrm{a}}+\frac{\mathrm{r}_{\mathrm{a}} \mathrm{H}}{\rho_{\mathrm{a}} \mathrm{c}_{\mathrm{p}}}
$$

In the two models based on Equation 4, for vegetation in general (PM1) and for grass, taking it as a reference surface (PM2), all the input field parameters were $\alpha_{0}, T_{0}, R_{n}, G, r_{s}$ and $r_{a}$ together microclimatic data and the ratio $\mathrm{ET} / \mathrm{ET}_{0}$ (Table 1). The field measurements were then correlated with remote sensing parameters described in the next section.

\subsubsection{Remote Sensing Parameters}

In the regional radiation balance (Figure 1), $\alpha_{0}$ is acquired from satellite-measured spectral radiances for each narrow band, followed by mathematical expressions for spectral integration and atmospheric correction. Regional $\mathrm{R}_{\mathrm{G}}$ in the present research was computed using interpolated measurements from seven pyrometers, which were calibrated periodically with a new sensor (Kipp \& Zonnen, Delft, the Netherlands), kept for this calibration.

The planetary albedo for each Landsat satellite band $\left(\alpha_{p_{b}}\right)$ is calculated as:

$$
\alpha_{\mathrm{p}_{\mathrm{b}}}=\frac{\mathrm{L}_{\mathrm{b}} \pi \mathrm{d}^{2}}{\mathrm{R}_{\mathrm{a}_{\mathrm{b}}} \cos \varphi}
$$

where $L_{b}$ is the spectral radiance for wavelengths of the band $b\left(\mathrm{~W} \mathrm{~m}^{-2} \mathrm{sr}^{-1} \mu \mathrm{m}^{-1}\right), \mathrm{d}$ is the relative earth-sun distance; $\mathrm{R}_{\mathrm{a}_{\mathrm{b}}}$ is the mean solar irradiance at the top of the atmosphere (or atmospheric irradiance) for each band ( $\mathrm{W} \mathrm{m}^{-2} \mu \mathrm{m}^{-1}$ ) and $\varphi$ the solar zenith angle. The broadband planetary albedo 
$\left(\alpha_{\mathrm{p}}\right)$ is obtained as the total sum of the different narrow-band $\alpha_{\mathrm{p}_{\mathrm{b}}}$ values according to weights for each band $\left(\mathrm{w}_{\mathrm{b}}\right)$.

$$
\alpha_{\mathrm{p}}=\sum \mathrm{w}_{\mathrm{b}} \alpha_{\mathrm{p}_{\mathrm{b}}}
$$

The weights for the different bands are computed as the ratio of the amount of incoming shortwave radiation from the sun at the top of the atmosphere in a particular band and the sum for all the bands. The bands 1 to 5 and 7 provide data for the visible and near infrared bands used for $\alpha_{0}$ calculations. Values of $\mathrm{w}_{\mathrm{b}}$ for the Landsat satellites are given in Table 2:

Table 2. Weighting coefficients $\left(\mathrm{w}_{\mathrm{b}}\right)$ for Landsat images

\begin{tabular}{lccccccc}
\hline Satellite & Band 1 & Band 2 & Band 3 & Band 4 & Band 5 & Band 6 & Band 7 \\
\hline Landsat 5 & 0.293 & 0.274 & 0.233 & 0.157 & 0.033 & - & 0.011 \\
Landsat 7 & 0.293 & 0.274 & 0.231 & 0.156 & 0.034 & - & 0.012 \\
\hline
\end{tabular}

The spectral radiance in band $6\left(\mathrm{~L}_{6}\right)$ of Landsat is converted into a radiation temperature applicable at the top of the atmosphere $\left(\mathrm{T}_{\mathrm{sat}}\right)$ by inversion of Plank's law in the $10.4-12.5 \mu \mathrm{m}$ bandwidth:

$$
\mathrm{T}_{\mathrm{sat}}=\frac{\mathrm{K}_{2}}{\ln \left(\frac{\mathrm{K}_{1}}{\mathrm{~L}_{6}+1}\right)}
$$

where $\mathrm{T}_{\text {sat }}$ is the brightness temperature $(\mathrm{K}) ; \mathrm{L}_{6}$ is the uncorrected thermal radiance from the land surface; and $K_{1}$ (607.76 and 666.09 for Landsat 5 and 7, respectively) and $K_{2}$ (1,260.56 and 1,282.71 for Landsat 5 and 7 , respectively) are conversion coefficients given in $\mathrm{mW} \mathrm{cm} \mathrm{sr}^{-1} \mu \mathrm{m}^{-1}$ and $\mathrm{W} \mathrm{m} \mathrm{mr}^{-1} \mu \mathrm{m}^{-1}$ for Landsat 5 and Landsat 7 , respectively.

Another important satellite parameter for ET modeling is the Normalized Difference Vegetation Index (NDVI) which is an indicator related to the land cover:

$$
N D V I=\frac{\alpha_{p_{(N \mathbb{R})}}-\alpha_{p_{(R E D)}}}{\alpha_{p_{(N I R)}}+\alpha_{p_{(R E D)}}}
$$

where $\alpha_{p_{(\mathrm{NIR})}}$ and $\alpha_{\mathrm{p}_{(\mathrm{RED})}}$ represent the planetary albedo over the ranges of wavelengths in the near infrared (NIR) and red (RED) regions of the solar spectrum, respectively.

\subsection{Study Region, Field Experiments and Agro-Meteorological Stations}

The São Francisco river basin encompasses several Brazilian states with a size of $636,920 \mathrm{~km}^{2}$. It is divided into four physiographic regions: The Upper, the Middle, the Low-Middle and the Lower São Francisco sub basins. The upstream region has an average annual precipitation of more than 2,000 mm. In the semi-arid and arid zones of the states of Bahia and Pernambuco, the rainfall drops to less than $350 \mathrm{~mm} \mathrm{yr}^{-1}$. Near the mouth of the river, oceanic influence gradually increases rainfall again to about $1,300 \mathrm{~mm} \mathrm{yr}^{-1}$. More than $50 \%$ of the territory of the basin is located in the semi-arid region of Brazil in the northeastern part of the country. Disturbed currents of South, North, East and West influence the climatology of this region. Excluding the places of high altitude, all areas in the Low-Middle sub-basin present annual averaged air temperatures higher than $24{ }^{\circ} \mathrm{C}$, even higher than $26{ }^{\circ} \mathrm{C}$ in the depressions 
at 200 to $250 \mathrm{~m}$ of altitude. The average maximum air temperature for this sub basin is $33{ }^{\circ} \mathrm{C}$ and the average minimum is $19^{\circ} \mathrm{C}$. The averaged monthly values are in the range from $17^{\circ} \mathrm{C}$ to $29^{\circ} \mathrm{C}$ [78] .

The experimental data set involving vineyards, mango orchards and natural vegetation, together with satellite images and agro-meteorological stations, were used for modeling and analyzing ET in the growing regions of the Low-Middle São Francisco river basin. Figure 4 shows the details of the entire basin, sub-basins, field experiments and agro-meteorological stations.

Figure 4. The São Francisco river basin and the semi-arid region studied. The agrometeorological stations (black) and the flux towers (white) on irrigated fruit crops (wine grape, table grape, mango orchard) and natural vegetation (caatinga) are indicated on the right side.

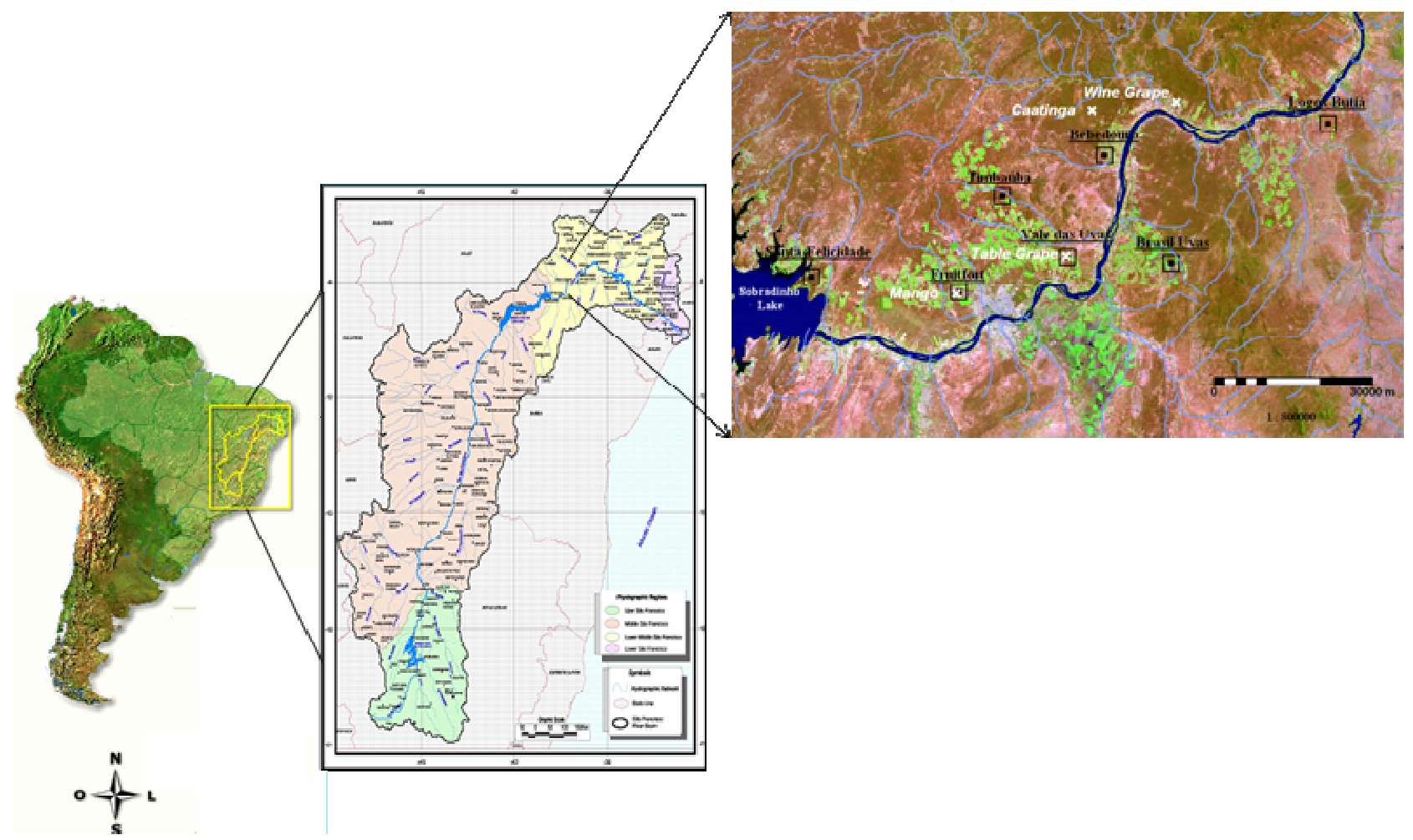

The four field experiments involved measurements of solar radiation, energy and water balances as well as microclimate conditions. Table 3 shows the coordinates, the methods of measurements, size of the plots and irrigation systems.

Table 3. Field energy balance experiments used for modeling actual evapotranspiration in the Low-Middle São Francisco river basin.

\begin{tabular}{lllll}
\hline Vegetation & $\begin{array}{l}\text { Location } \\
\text { (latitude, longitude) }\end{array}$ & $\begin{array}{l}\text { Area } \\
\text { (ha) }\end{array}$ & $\begin{array}{l}\text { Irrigation } \\
\text { system }\end{array}$ & $\begin{array}{l}\text { Method of } \\
\text { measurements }\end{array}$ \\
\hline Wine grape & $9^{\circ} 02^{\prime} 24.53^{\prime \prime} \mathrm{S} ; 40^{\circ} 11^{\prime} 13.49^{\prime \prime} \mathrm{W}$ & 4.13 & Drip & Bowen ratio \\
Table grape & $9^{\circ} 18^{\prime} 40.84^{\prime \prime} \mathrm{S} ; 40^{\circ} 22^{\prime} 29.47^{\prime \prime} \mathrm{W}$ & 5.13 & Micro sprinkler & Bowen ratio \\
Mango & $9^{\circ} 22^{\prime} 32.20^{\prime \prime} \mathrm{S} ; 40^{\circ} 33^{\prime} 54.23^{\prime \prime} \mathrm{W}$ & 11.92 & Micro sprinkler & Eddy covariance \\
Caatinga & $9^{\circ} 03^{\prime} 30.71^{\prime \prime} \mathrm{S} ; 40^{\circ} 19^{\prime} 45.21^{\prime \prime} \mathrm{W}$ & $\mathrm{N} / \mathrm{A}$ & Not irrigated & Eddy covariance \\
\hline
\end{tabular}


The measurements covered two growing seasons of irrigated fruit crops - wine grape, table grape, mango orchard and two years with different rainfall conditions in natural vegetation - caatinga.

\subsection{Field and Satellite Data}

\subsubsection{Field Measurements}

The weather data were taken from seven automatic agro-meteorological stations shown in black in Figure 4. The geographic positions are described in Table 4. They were equipped with pyranometers, anemometers, net radiometers, sensors for air temperature and relative humidity, rain gauges, and soil heat flux plates. The data were available for every 30 minutes and used for the regional calculation of the radiation balance terms (Figure 1) and $\mathrm{ET}_{0}$ by FAO Penman-Monteith method [61] allowing the acquirement of daily and annual ET $[28,37,48]$.

Table 4. Agro-meteorological stations used for the regional radiation balance and reference evapotranspiration calculations.

\begin{tabular}{llll}
\hline Station & Latitude & Longitude & State \\
\hline Fruitfort & $09^{\circ} 22^{\prime} 22.99^{\prime \prime} \mathrm{S}$ & $40^{\circ} 33^{\prime} 40.47^{\prime \prime} \mathrm{W}$ & Pernambuco \\
Vale das Uvas & $09^{\circ} 18^{\prime} 50.93^{\prime \prime} \mathrm{S}$ & $40^{\circ} 22^{\prime} 22.98^{\prime \prime} \mathrm{W}$ & Pernambuco \\
Bebedouro & $09^{\circ} 08^{\prime} 12.35^{\prime \prime} \mathrm{S}$ & $40^{\circ} 18^{\prime} 31.51^{\prime \prime} \mathrm{W}$ & Pernambuco \\
Timbaúba & $09^{\circ} 12^{\prime} 28.75^{\prime \prime} \mathrm{S}$ & $40^{\circ} 29^{\prime} 05.21^{\prime \prime} \mathrm{W}$ & Pernambuco \\
Santa Felicidade & $09^{\circ} 20^{\prime} 40.24^{\prime \prime} \mathrm{S}$ & $40^{\circ} 48^{\prime} 59.42^{\prime \prime} \mathrm{W}$ & Bahia \\
Brasil Uvas & $09^{\circ} 19^{\prime} 26.71^{\prime \prime} \mathrm{S}$ & $40^{\circ} 11^{\prime} 48.67^{\prime \prime} \mathrm{W}$ & Bahia \\
Logos Butiá & $09^{\circ} 05^{\prime} 01.79^{\prime \prime} \mathrm{S}$ & $39^{\circ} 55^{\prime} 28.78^{\prime \prime} \mathrm{W}$ & Bahia \\
\hline
\end{tabular}

The BR method was used to estimate the partition of the net available energy into sensible and latent heat fluxes in vineyards, while in mango orchard and natural vegetation (caatinga) this was done by EC measurements [5,13,14].

In both vineyards (wine grape and table grape), the sensors were installed at the centre of the plots shown in Figure 4 and described in Table 3. The wine grape was trained vertically at a height of $1.6 \mathrm{~m}$ with the plants spaced at $1.2 \mathrm{~m} \times 3.5 \mathrm{~m}$, while the table grape was spaced at $3.5 \mathrm{~m} \times 4.0 \mathrm{~m}$ with an overhead horizontal trellis system of $1.8 \mathrm{~m}$. The gradients of air temperature and vapor pressure were calculated by wet and dry thermocouples of copper/constantan at 0.5 and $1.5 \mathrm{~m}$ above the canopies. The surface albedo $\left(\alpha_{0}=\mathrm{R}_{\mathrm{R}} / \mathrm{R}_{\mathrm{G}}\right)$ was measured through incident $\left(\mathrm{R}_{\mathrm{G}}\right)$ and reflected $\left(\mathrm{R}_{\mathrm{R}}\right)$ global solar radiation acquired with pyranometers faced up and down (model Eppley, number 19,579, Rhode Island, RI, USA). The net radiation $\left(\mathrm{R}_{\mathrm{n}}\right)$ was measured over the canopies with two net radiometers (model NR-Lite, Kipp \& Zonnen, Delft, the Netherlands). All radiation sensors were placed at $1 \mathrm{~m}$ above the canopies. The soil heat flux $(\mathrm{G})$ was obtained with four heat flux plates (HFT3-L, REBS, Radiation and Energy Balance Systems, Seattle, WA and Hukseflux, Delft, the Netherlands) at $2 \mathrm{~cm}$ soil depth and $0.5 \mathrm{~m}$ from the plants. Wind speed was measured with anemometers (R. M., Young wind Sentry, 03101, MI, USA) at two levels, i.e., 1.0 and $2.0 \mathrm{~m}$ above the canopies. Air temperature and relative humidity at $0.5 \mathrm{~m}$ from the leaves were obtained with probes from Vaisala (model HMP 35A, Helsinki, Finland) and Sky (SKH 2013, Sky instruments LTD, Llandrindod Wells, UK). 
In the vineyards, $\lambda \mathrm{E}$ and $\mathrm{H}$ were calculated by using the Bowen ratio, as a function of the gradients of air temperature and vapor pressure above the canopies. Missing or erroneous ET data from BR system were filled by using the relation of $\lambda E$ with the available energy $\left(R_{n}-G\right)$ for specific periods of time. As the vineyards are inside large irrigated farms, with several plots with the same crop, the BR method is considered accurate with $\mathrm{H}$ representing only 12 and $18 \%$ of $\mathrm{R}_{\mathrm{n}}$ for table and wine grapes, respectively $[5,14]$.

The EC system (EC) in mango orchard determined $\mathrm{H}$ and $\lambda \mathrm{E}$ by a three-axis sonic anemometer (Model CSAT3, Campbell Scientific, Logan, UT, USA) and a krypton hygrometer (Model KH20, Campbell Scientific, Logan, UT, USA), respectively. The trees were spaced in a regular square pattern at $10 \mathrm{~m} \times 10 \mathrm{~m}$, with an average height of $5.5 \mathrm{~m}$. The sensors were set at $3 \mathrm{~m}$ above the crown of a tree with a sampling frequency of $16 \mathrm{~Hz}$. Corrections to water flux due to density fluctuations introduced by the fluxes of sensible and latent heat flux [79], oxygen absorption [80] and frequency losses [81] were applied. $\mathrm{R}_{\mathrm{n}}$ was acquired with one net radiometer (model NR-Lite, Kipp \& Zonnen, Delft, the Netherlands) at a height of $2.5 \mathrm{~m}$ above the canopy. At this same height the surface albedo was measured with pyranometers faced up and down (model Eppley, number 19579, RI, USA). The soil heat flux $(\mathrm{G})$ was acquired with two heat flux plates (model HFT3-L, REBS, Radiation and Energy Balance Systems, Seattle, WA, USA) at $2 \mathrm{~cm}$ soil depth and bellow the projected tree crown at $100 \mathrm{~cm}$ from the trunk. Air temperature and relative humidity near the leaves were measured with a probe (SKH 2013, Sky instruments LTD, Llandrindod Wells, UK) installed at the same height of the radiation sensors $[13,14]$.

The EC system over caatinga was installed at $11 \mathrm{~m}$ height above the ground. The natural vegetation is a mixture of species with a mean height of $8 \mathrm{~m}$. The system consisted of a sonic anemometer from the same manufacturer as for mango orchard and a gas analyzer (LI7500, LI-COR, Lincoln, NE, USA) with the same sampling frequency, datalogger and corrections as for mango orchard. All components of short and long wave radiation were measured with pyranometers and pyrgeometers facing up and down (Kipp \& Zonnen, Delft, the Netherlands) at a height of $10 \mathrm{~m}$ from the ground. $\mathrm{R}_{\mathrm{n}}$ was acquired with a net radiometer at the same height of the other radiation sensors and $G$ was measured with one flux plate at $2 \mathrm{~cm}$ soil depth. Both the net radiometer and the flux plates were from the same manufacturer as for mango orchard. Microclimatic measurements of air temperature and relative humidity were taken above the vegetation with a probe from Vaisala (model HMP 45C-L, Helsinki, Finland) at the same height of the radiation sensors.

The data quality from EC systems, in mango orchard and caatinga, was verified by studying the energy balance closure: fluxes $(\lambda E+H)$ and available energy $\left(R_{n}-G\right)$ were compared at a daily time scale, being $88 \%$, with a RMSE of $1.7 \mathrm{MJ} \mathrm{m}^{-2} \mathrm{~d}^{-1}$, evidenced the good quality of the dataset. The gaps in ET data from the EC systems, mainly during the rainy periods for the krypton data in mango orchard, were filled by the equation resulting from the energy closure. A closure error of 10 to $30 \%$ seems to occur frequently with EC - based latent heat flux estimates. A summary paper of 22 flux sites indicated a general lack, with a mean imbalance in the order of 20\% [82]. Available energy systematically exceeding measured fluxes have been published $[83,84,85]$. The lack of energy balance closure can also be associated with measurement errors in $\mathrm{R}_{\mathrm{n}}$ and $\mathrm{G}$, but not completely explained by this uncertainty, because EC systems have their own sources of error [83]. Further to systematic biases in the instrumentation, the general hypothesis about this lack can be explained by sampling errors 
related to different footprints, neglected energy sinks, loss of low and/or high frequency contributions to the turbulent heat flux and advection of scalars [86].

\subsubsection{Remote Sensing Measurements}

The regional radiation balance calculations were done from Landsat Thematic Mapper (TM) and Enhanced Thematic Mapper (ETM+). The cloud free satellite images used are in Table 5.

Table 5. Landsat satellite data during the period from September 2001 to January 2007 and the experiments used for calibrations and validations.

\begin{tabular}{llll}
\hline Date & DOY & Satellite & Field experiments \\
\hline 10 September 2001 & 253 & Landsat 7 & Wine grape \\
04 October 2001 & 277 & Landsat 5 & Wine grape \\
06 July 2003 & 187 & Landsat 5 & Table grape, Caatinga \\
24 September 2003 & 267 & Landsat 5 & Table grape, Caatinga \\
12 October 2004 & 286 & Landsat 5 & Mango orchard, Caatinga \\
14 November 2004 & 328 & Landsat 5 & Mango orchard, Caatinga \\
15 October 2005 & 288 & Landsat 5 & Mango orchard, Caatinga \\
16 November 2005 & 320 & Landsat 5 & Mango orchard, Caatinga \\
30 July 2006 & 211 & Landsat 5 & Mango orchard, Caatinga \\
22 January 2007 & 022 & Landsat 5 & Mango orchard, Caatinga \\
\hline
\end{tabular}

* DOY: Day of the year

The Landsat satellites have a 16-day overpass at around 09:30 hours local time but only a maximum of two images per year were free of clouds. They were used together with the results of field experiments and interpolated weather data from the network of seven agro-meteorological stations (Tables 3, 4 and 5).

Landsat 5 Thematic Mapper (TM) and Landsat 7 Enhanced Thematic Mapper (ETM+) are sun-synchronous, near-polar satellites that provide spectral radiance measurements in narrow bands. The bands 1 to 5 and 7 give data for the visible and near infrared bands. The pixel size for these bands is $30 \mathrm{~m}$ by $30 \mathrm{~m}$. The band 6 provides data for long wave (thermal) radiation, with a pixel size of $60 \mathrm{~m}$ by $60 \mathrm{~m}$ for Landsat 7 and $120 \mathrm{~m}$ by $120 \mathrm{~m}$ for Landsat 5 . Both Landsat satellites have a swath width of $185 \mathrm{~km}$ and an orbit of $705 \mathrm{~km}$ (about 435 miles) above the earth.

For Landsat 5 and 7 the spectral radiance for each band $\left(\mathrm{L}_{\mathrm{b}}\right)$ is computed as [78]:

$$
\mathrm{L}_{\mathrm{b}}=\left[\frac{\mathrm{L}_{\mathrm{MAX}}-\mathrm{L}_{\mathrm{MIN}}}{\mathrm{QCAL}_{\mathrm{MAX}}-\mathrm{QCAL}_{\mathrm{MIN}}}\right]\left(\mathrm{DN}-\mathrm{QCAL}_{\mathrm{MIN}}\right)+\mathrm{L}_{\mathrm{MIN}}
$$

where DN is the digital number of each pixel, $\mathrm{L}_{\mathrm{MAX}}$ and $\mathrm{L}_{\mathrm{MIN}}$ are calibration constants, $\mathrm{QCAL}_{\mathrm{MAX}}$ and $\mathrm{QCAL}_{\mathrm{MIN}}$ are the highest and lowest range of values for rescaled radiance in $\mathrm{DN}$. The units for $\mathrm{L}_{\mathrm{b}}$ are $\mathrm{W} \mathrm{m}{ }^{-2} \mathrm{sr}^{-1} \mu \mathrm{m}^{-1}$.

For Landsat 5, $\mathrm{QCAL}_{\mathrm{MAX}}=255$ and $\mathrm{QCAL}_{\mathrm{MIN}}=0$. For Landsat 7 with header file data on gains and biases, a simpler equation for $\mathrm{L}_{\mathrm{b}}$ is given:

$$
\mathrm{L}_{\mathrm{b}}=(\text { Gain } \times \mathrm{DN})+\text { Bias }
$$


where Gain and Bias refer to the values given in the header file.

\section{Results and Discussion}

\subsection{Model Validations}

To test the validity of the equations involving the PM1 and PM2 models, field and remote sensing parameterizations were used. They have been applied to all 10 different Landsat images throughout the equations from Table 1 and Figures 1 and 2. The ET results were validated with field measurements from BR and EC systems in the contrasting hydrological ecosystems of irrigated crops and natural vegetation in the Brazilian semi-arid conditions. Figure 5 shows the scatter plots for the daily ET which resulted from the two models. The satellite values were taken from the Landsat pixels where the flux towers were installed, representing an area of $900 \mathrm{~m}^{2}$.

Figure 5. Relationships between satellite and field measurements of daily actual evapotranspiration. (a) using the modeled evapotranspiration resistances (PM1). (b) using the modeled $\mathrm{ET} / \mathrm{ET}_{0}$ ratio (PM2).

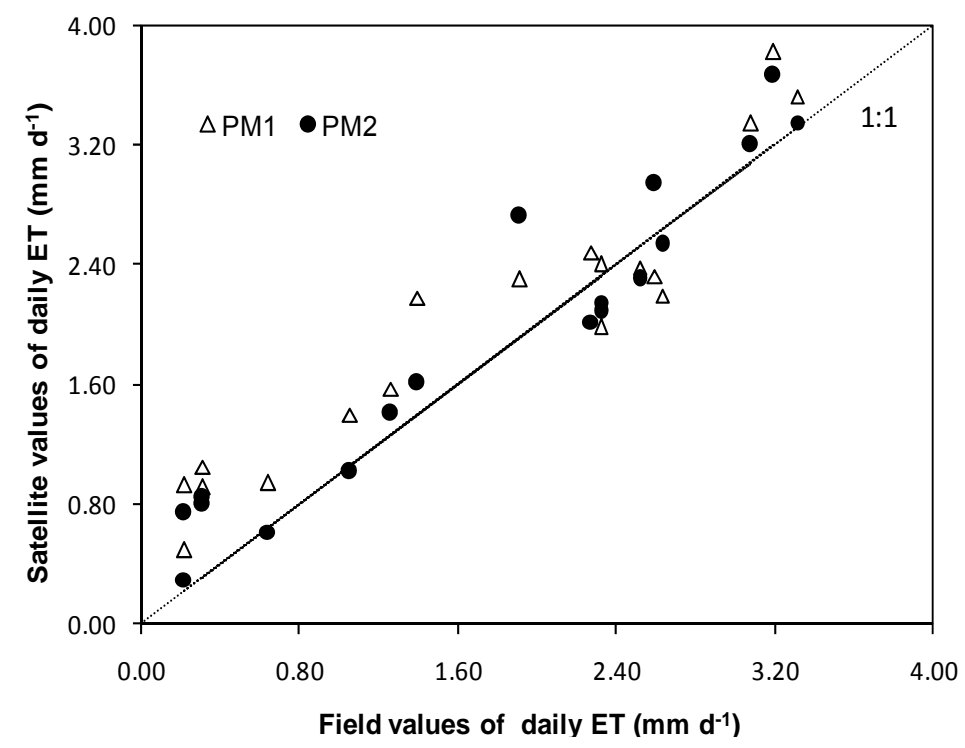

The results showed good agreement for both models, but better for PM2 $\left(\mathrm{R}^{2}=0.79\right.$ and 0.89 and a root mean square error-RMSE of 0.44 and $0.34 \mathrm{~mm} \mathrm{~d}^{-1}$, for PM1 and PM2, respectively). While this last model fitted more the line 1:1, explaining $89 \%$ of the variance, the PM1 model, explaining $79 \%$ of the variance, overestimated the field values for the low ET rates of natural vegetation.

The lower regression coefficient and higher RMSE for the PM1 model can be due to the fact that the weather data from the agro-meteorological stations are not representative of the microclimatic conditions of the caatinga. One can see in Figure 5 that better results of PM1 is for higher values of ET, corresponding to irrigated crops, independently of their microclimate, as the agro-meteorological stations are inside of irrigated areas. Actual projects in the Low-Middle São Francisco river basin foresee the installation of new stations in the region, which will cover more areas inside the natural vegetation. 
To verify the influence of instantaneous radiation and energy balance components determination (Figure 1 and Table 1) on the instantaneous values of $\lambda E$ from Equation 4, the scatter plots of these components involved in the processes were constructed (Figure 6).

Figure 6. Relationships between instantaneous radiation and energy balance components from satellite (subscript SAT) and from field measurements (subscript FIELD): $\lambda \mathrm{E}$ - latent heat flux; $\mathrm{AE}$ - Available energy; $\mathrm{R}_{\mathrm{n}}$ - net radiation; $\mathrm{G}$ - soil heat flux.

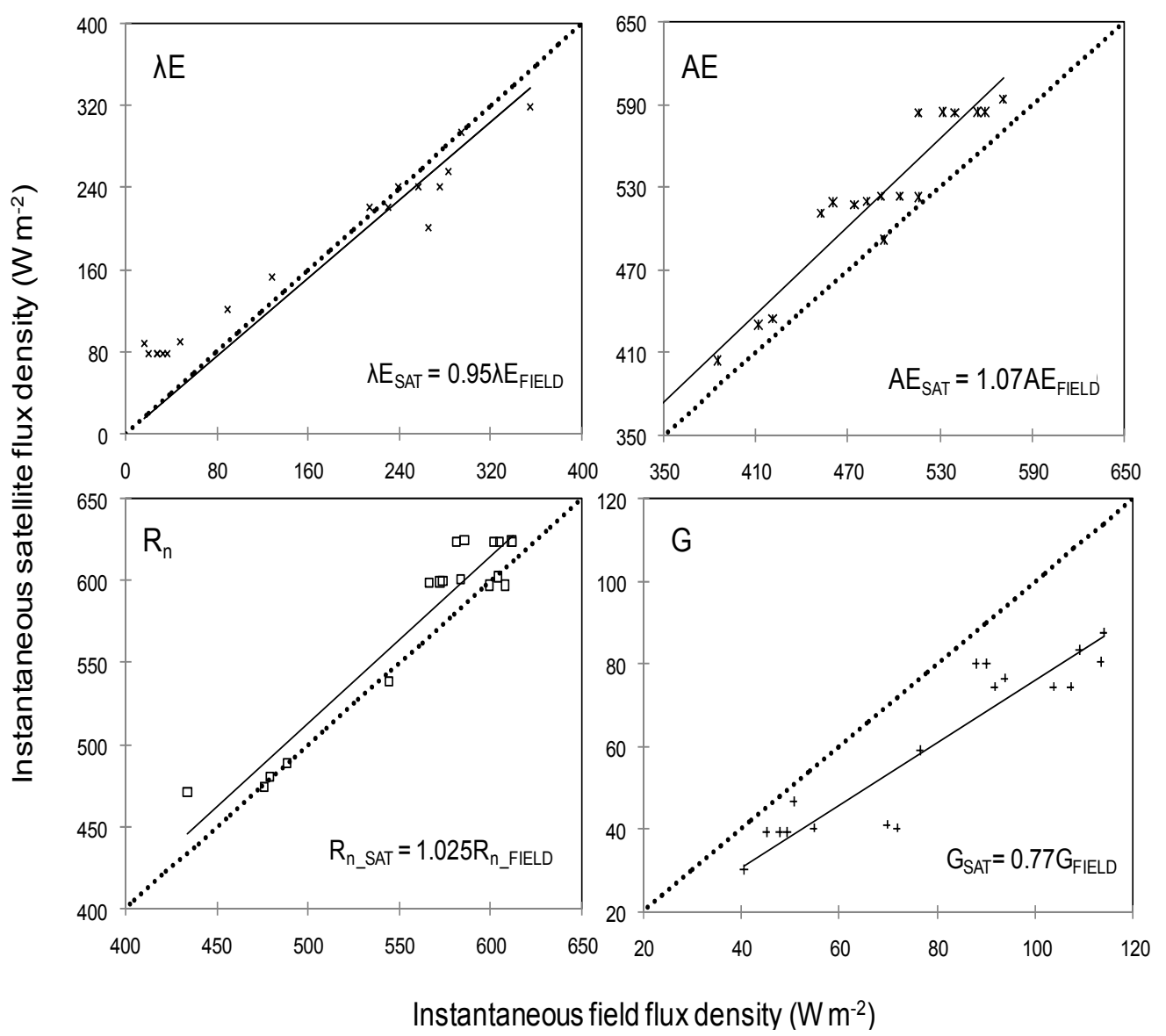

Reasonable agreement was found for $\lambda \mathrm{E}$, with a coefficient of determination of $\mathrm{R}^{2}=0.78$, a RMSE of $39.7 \mathrm{~W} \mathrm{~m}^{-2}$, and an average deviation of $5 \%$. The differences occurred typically for the lower values because the weather data used in Equation 4 are from agro-meteorological stations inside of irrigated areas. This is confirmed by the good correlation shown in the scatter plot of the available energy (AE), with a $\mathrm{R}^{2}=0.91$ and a RMSE of $38.6 \mathrm{~W} \mathrm{~m}^{-2}$. In general the AE satellite values overestimated the field values a little, which was due to an overestimation in $\mathrm{R}_{\mathrm{n}}$. Despite this overestimation, excellent agreement was found for $\mathrm{R}_{\mathrm{n}}$, with an $\mathrm{R}^{2}$ of 0.92 and a RMSE of only $21.8 \mathrm{~W} \mathrm{~m}^{-2}$. This overestimation could be related to the low coefficient of determination for $\varepsilon_{\mathrm{a}}$ together with an underestimation in $\alpha_{0}$ (Table 1). The largest differences from the line 1:1 were found for $G$, however still with good statistical results $\left(\mathrm{R}^{2}=0.85\right.$ and RMSE of $\left.21.7 \mathrm{~W} \mathrm{~m}^{-2}\right)$. The biggest distances were verified for higher values, representative of caatinga where $G$ was measured with just one flux plate.

In the case of PM2, all the calculations for obtaining $R_{n}$ and $G$ are not necessary (Table 1 and Figure 1). The ratio $\mathrm{ET} / \mathrm{ET}_{0}$ is directly modeled with only three remote sensing parameters, which are related to vegetation. In addition, there is a small difference between the instantaneous and daily values 
of $\mathrm{ET} / \mathrm{ET}_{0}$ (Figure 3d). The interpolated values of $\mathrm{ET}_{0}$ by a Geographic Information System (GIS) yield a better characterization of the spatial climatic variation and, in case of the satellite without thermal bands, one can incorporate grids of $\mathrm{T}_{\mathrm{a}}$ instead of images of $\mathrm{T}_{0}$ in applying the equation for $\mathrm{ET} / \mathrm{ET}_{0}$ estimation from Table 1, with different regression coefficients, even with lower accuracy. Although $T_{a}$ being affected by each surface, the inclusion of $\alpha_{0}$ and NDVI can reduce the errors, because these last remote sensing parameters are characteristics of the different kind of vegetation and moisture status. When $\mathrm{T}_{\mathrm{a}}$ was used instead $\mathrm{T}_{0}$ in the relation for ET/ET $\mathrm{E}_{0}$ in Table 1 the coefficients became $\mathrm{a}=2.3$ and $\mathrm{b}=-0.011$ with a $\mathrm{R}^{2}$ of 0.82 . These last statistical results showed the suitability for using grids of $\mathrm{T}_{\mathrm{a}}$ in the case of a satellite with high spatial resolution but without a thermal band. The possibility of using interpolated weather data, including $T_{a}$, together with remotely vegetative indexes available from MODIS images, has been demonstrated for ET regionalization in Australia [23].

Another advantage of the PM2 model is that it can be applied without the need to identify the extreme conditions, being also suitable for the rainy periods. The local calibrated SEBAL algorithm was tested in the Low-Middle São Francisco river basin [27] with good agreement between field and Landsat measurements of daily ET ( $\mathrm{R}^{2}$ of 0.91 and RMSE of $\left.0.38 \mathrm{~mm} \mathrm{~d}^{-1}\right)$. However, to consider the necessary extreme conditions, EC towers were used for flux measurements in hydrological contrasting surfaces in the study region, to not consider ET null during the rainy season. The disadvantage is that EC systems are costly and operationally difficult, as compared with the parameterizations of the PM2 model, which needs only three satellite parameters and permanent agro-meteorological stations, which would also be useful for other important crop management applications such as ET-based irrigation scheduling.

Considering the better performance and simplicity of PM2, it was chosen and tested whether it is sufficiently robust and accurate for the task of ET determination at different spatial scales in the Low-Middle São Francisco river basin. In addition, the relation for $r_{s}$ depicted in Table 1 and Figure 3a was used for the classification of irrigated areas and natural vegetation. Furthermore both parameters $r_{s}$ and $\mathrm{ET} / \mathrm{ET}_{0}$ can be useful to infer soil water conditions. Because of the reasons explained for using the modeled ratio $\mathrm{ET} / \mathrm{ET}_{0}$ together with grids of daily $\mathrm{ET}_{0}$, it was concluded that this approach has considerable potential for estimating ET at different time and spatial scales in hydrological basins with the availability of agro-meteorological stations. The challenges faced to make the model applicable in other river basins are the implementation of a net of agro-meteorological stations to combine weather data with satellites measurements at different spatial and temporal resolutions and to test the algorithm over a more diverse range of ecosystems.

\subsection{Land Use Change}

Even with PM1 model not being chosen for ET calculations, the equation for $\mathrm{r}_{\mathrm{S}}$ shown in Table 1 and in Figure 3a was applied to infer the soil moisture conditions for a simplified vegetation classification. The satellite images of the study region were layered with the shapes of the main fruit growing regions in the Pernambuco (Petrolina, Lagoa Grande and Santa Maria da Boa Vista) and Bahia (Juazeiro and Casa Nova) states, involved by the net of agro-meteorological stations to identify the main direction of the quick land use change, highlighting the best possibility for the irrigation expansion. 
Figure 7 shows the satellite overpass images of $r_{s}$ representative for the dry (Figure 7a) and for the rainy (Figure $7 \mathrm{~b}$ ) periods in the semi-arid region comprised of the net of agro-meteorological stations.

Figure 7. Images of the satellite overpass surface resistance for the region comprised of the net of agro-meteorological stations in the Low-Middle São Francisco river basin. (a) October 2005. (b) January 2007.

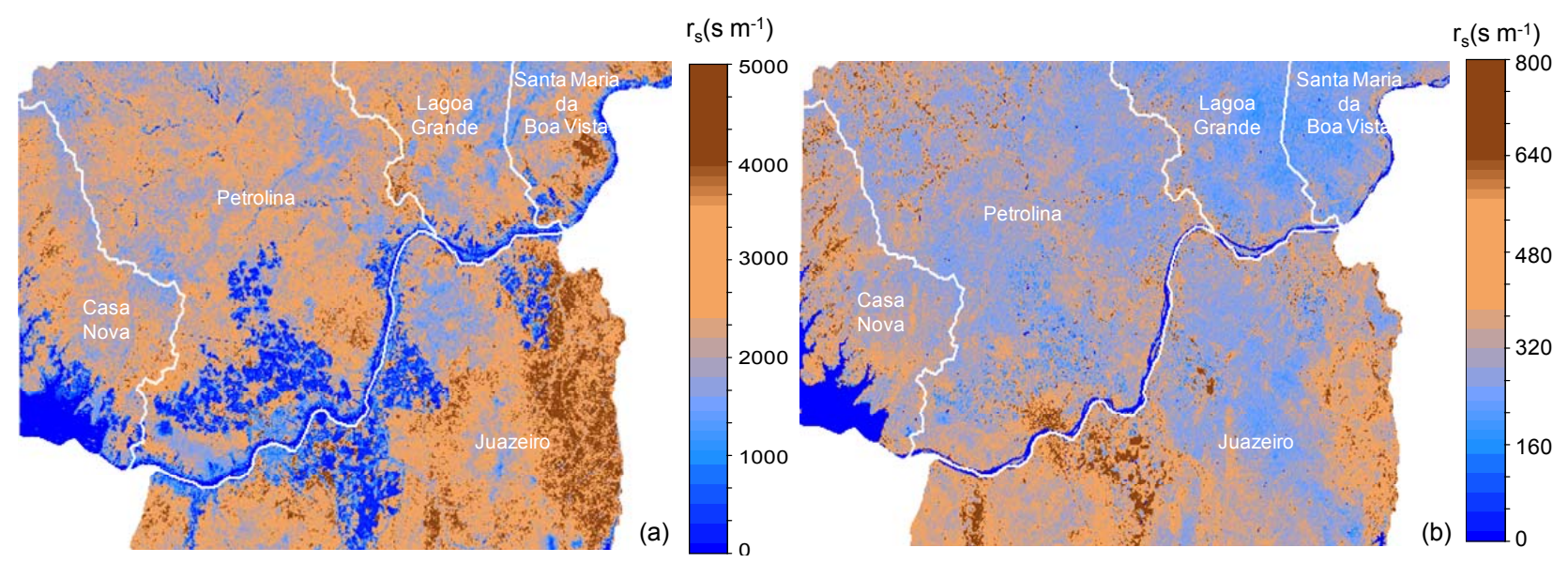

One can see that during the first period, the irrigated crops with much lower values than those for natural vegetation are strongly highlighted by the blue areas. In general, caatinga shows $r_{s}$ values higher than $800 \mathrm{~s} \mathrm{~m}^{-1}$ during this dry period of the year. Inside the wet period there is more homogeneity in the whole area and both, irrigated and not irrigated vegetated areas, present values lower than $800 \mathrm{~s} \mathrm{~m}^{-1}$. The relation of $\mathrm{r}_{\mathrm{s}}$ with soil moisture shows the suitability of estimating this last important water variable in semi-arid regions which involve a mixture of ecosystems. According to the location of the field experiments shown in Figure 4, the maximum values are for caatinga (average of $1,937 \mathrm{~s} \mathrm{~m}^{-1}$ ). Wine grape and mango orchard present similar values around $130 \mathrm{~s} \mathrm{~m}^{-1}$, while table grapes present the lowest ones, averaging $74 \mathrm{~s} \mathrm{~m}^{-1}[14]$.

Considering that the quick land use change by the replacement of natural vegetation with irrigated crops can cause environmental problems, it becomes very important to make a historical picture at the growing regions level about this replacement. Figure 8 presents the evolution of the irrigated areas during the period from 2002 to 2006 for the growing regions involved in the net of agro-meteorological stations, by using the classified satellite data. The total irrigated areas were calculated by summing the number of pixels with $r_{s}$ values lower than $800 \mathrm{~s} \mathrm{~m}^{-1}$ and multiplying this number by the area of each pixel. Images of 2001 and 2003 were interpolated to give the situation for 2002 and the image of 2006 gave the situation for this year (Table 4).

Although Petrolina-PE and Juazeiro-BA present the biggest irrigated areas, the increments throughout the years (2002-2006) are lower (213 and 171\%) than those for Santa Maria-PE (275\%) and for Lagoa Grande-PE (260\%). The municipality of Casa Nova-BA showed an intermediary value of $198 \%$ being the best option for irrigation expansion. 
Figure 8. Evolution of irrigated growing areas comprised of the net of agro-meteorological stations, in the Low-Middle São Francisco river basin.

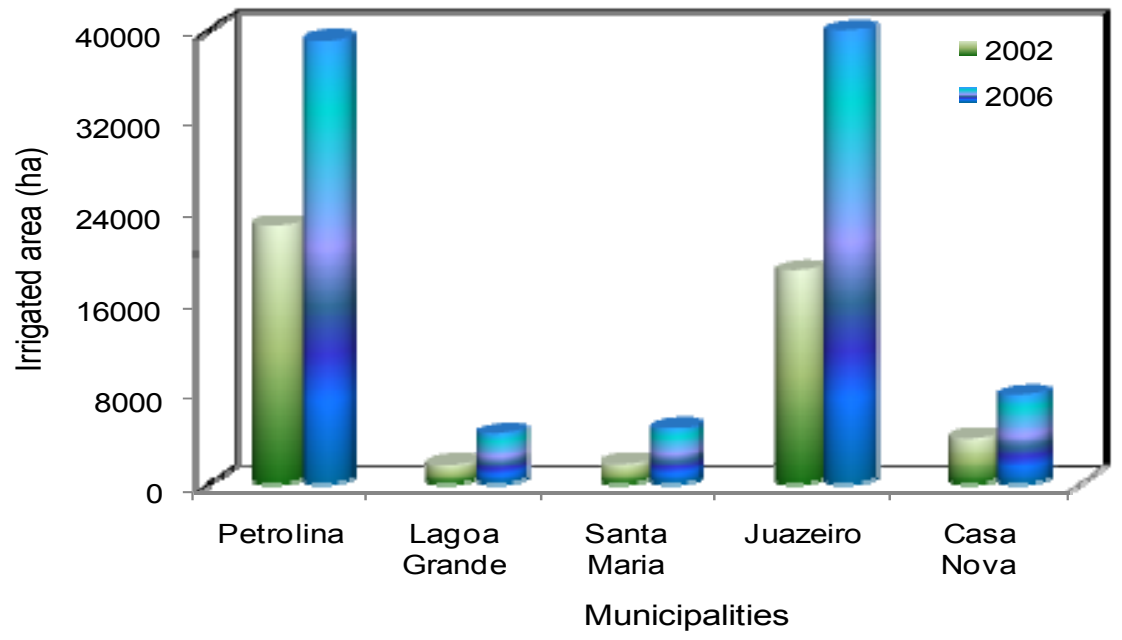

The most important commercially irrigated crops in the semi-arid region of Brazil are vineyards and mango orchards, being the main responsible vegetation for the quick land use change, growing mainly in Petrolina-PE and Juazeiro-BA. Figure 9a shows the evolution of the areas with the first crop, while Figure $9 \mathrm{~b}$ depicts the increment for the second crop in the growing regions of Petrolina-PE and Juazeiro-BA based on the data from Brazilian Institute for Geography and Statistics (IBGE).

Figure 9. Evolution of cultivated areas with vineyards and mango orchards for the centers of development Petrolina-PE/Juazeiro-BA in the Low-Middle São Francisco river basin.

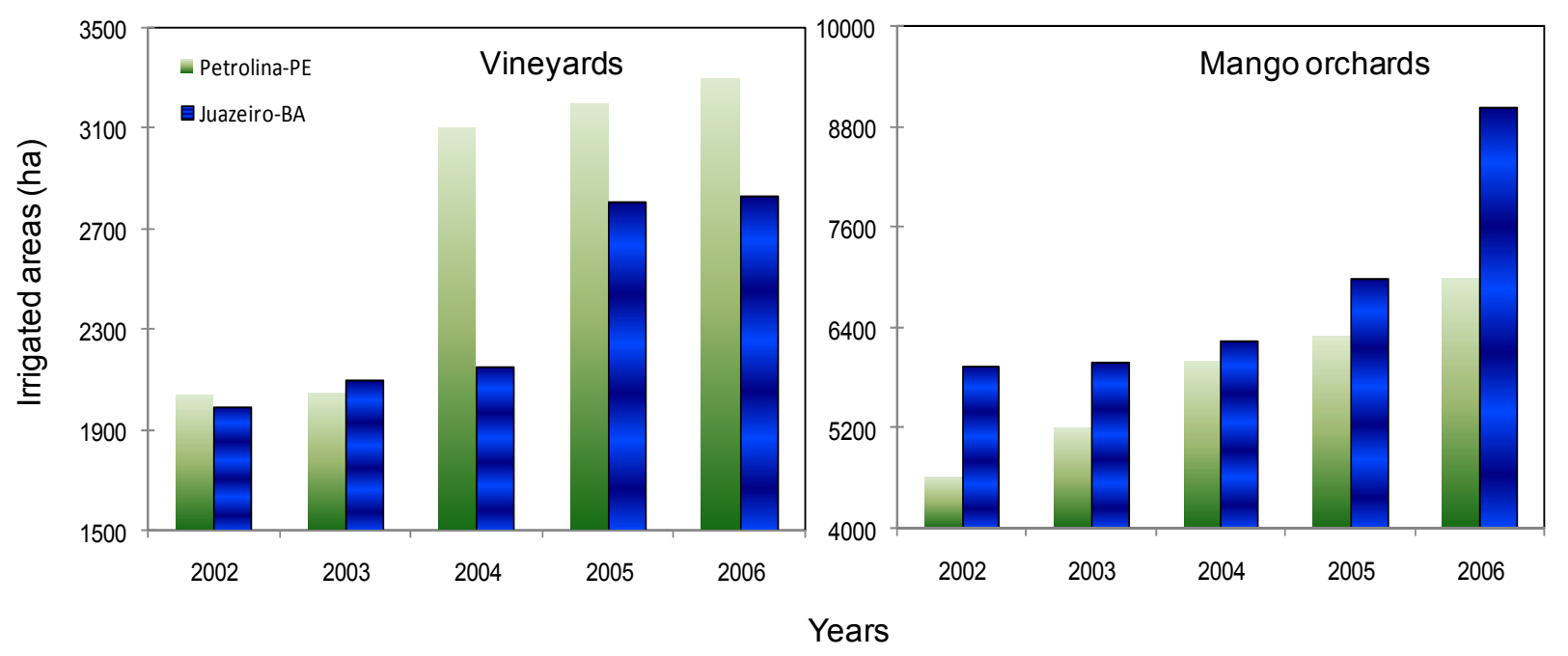

In the case of Petrolina-PE, the larger increase is for vineyards, while in Juazeiro-BA the biggest area is for mango orchards. The highest increment for the first crop was verified between 2003 and 2004 in Petrolina-PE, when the cultivated area increased 151\%. In the case of mango orchards the most significant period was from 2005 to 2006 in Juazeiro-BA (129\%). The agricultural water usage in both growing regions is highly productive. These cities have increased in terms of exports, and are good examples of converting marginal savannah land into a booming rural development; however the 
irrigation management requires full attention to tools for analysis of the regional ET for planning the expansion of irrigated areas.

\subsection{Regional Evapotranspiration}

As PM2 model uses the ratio $\mathrm{ET} / \mathrm{ET}_{0}$, the values of this ratio were also investigated for the same periods of the year as for $\mathrm{r}_{\mathrm{s}}$ (Figure 10).

Figure 10. Images of the satellite overpass $\mathrm{ET} / \mathrm{ET}_{0}$ for the region comprised of the net of agro-meteorological stations in the Low-Middle São Francisco river basin. (a) October 2005. (b) January 2007.

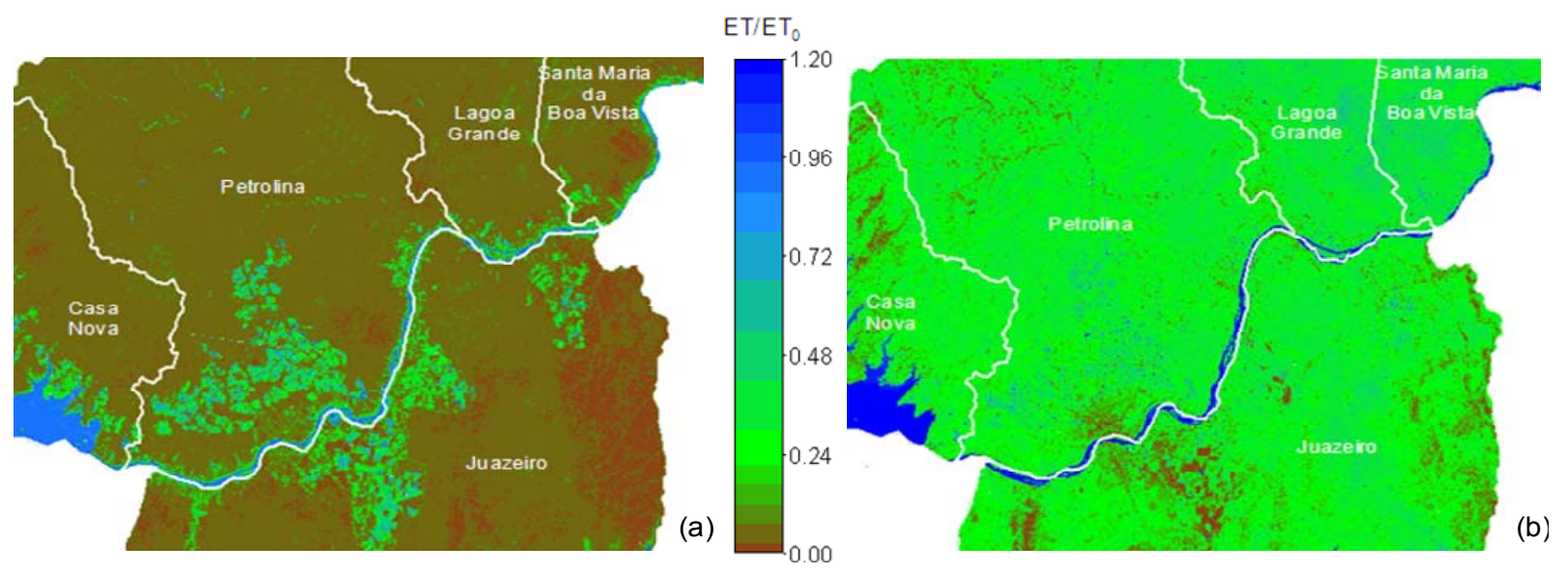

The same effects of the soil moisture conditions are evidenced as in the case of $r_{s}$. During the dry conditions (Figure 10a), the ET/ET 0 values for irrigated crops are near 1.00 because the water supply reduces the heat losses to the atmosphere while for caatinga this ratio ranges from 0.00 to 0.20 , as it converts the biggest part of the available energy into $\mathrm{H}$ during this period of the year. Inside the wet season (Figure 10b), the moisture conditions are more homogeneous, making the values for caatinga in some cases around 0.50 , similar to those for irrigated crops. During this season, a higher portion of the available energy in natural vegetation is converted into $\lambda \mathrm{E}$ and, in most commercial farms, the irrigation is stopped while the rainfall keeps the soil uniformly wet for all ecosystems. For complete growing seasons, crops with micro sprinkler system in general present mean values of ET/ET ${ }_{0}$ around 0.90, while for drip irrigated systems they are around $0.75-0.80$. Considering the period of the year, involving different soil moisture conditions, the average value for caatinga is 0.30 [78].

The variation of the modeled $\mathrm{ET} / \mathrm{ET}_{0}$ ratio with these extreme seasonal moisture conditions and the similarity with field values is encouraging to simulate timing and magnitude of ET, capturing the strong contrast between the four sites depicted in Figure 4. The ratio can also be a good option as an input parameter for the soil moisture estimations at the regional scale, similar to the EF reported in the international literature. Values of EF for irrigated cotton and perennial vegetation (vineyards and orchards) were found varying from 0.40 , when the crops started to be irrigated, to $0.70-0.90$ during the irrigation season in the Gediz basin (Turkey) [87]. A grazing steppe in central Mongolia presented seasonal values of EF following the variation in leaf areas and rainfall events during the dry-wet cycles [88]. For a tropical watershed in the Kenyan Rift Valley with natural meadows, the values of EF were 0.70 during the wet season and 0.10 during the dry season [89]. The behavior of $\mathrm{ET} \mathrm{ET}_{0}$ for 
irrigated crops and natural vegetation in different soil moisture conditions of the actual study was thus similar to the behavior of EF reported in the literature.

The daily values of ET involving different periods of the year (before, just after, and during the rainy season) in the study region are presented in Figure 11.

Figure 11. Daily actual evapotranspiration (ET) for the region comprised of the net of agro-meteorological stations in the Low-Middle São Francisco river basin. (a) wet season in January 2007. (b) end of the rainy season in July of 2006. (c) dry season in October 2005.

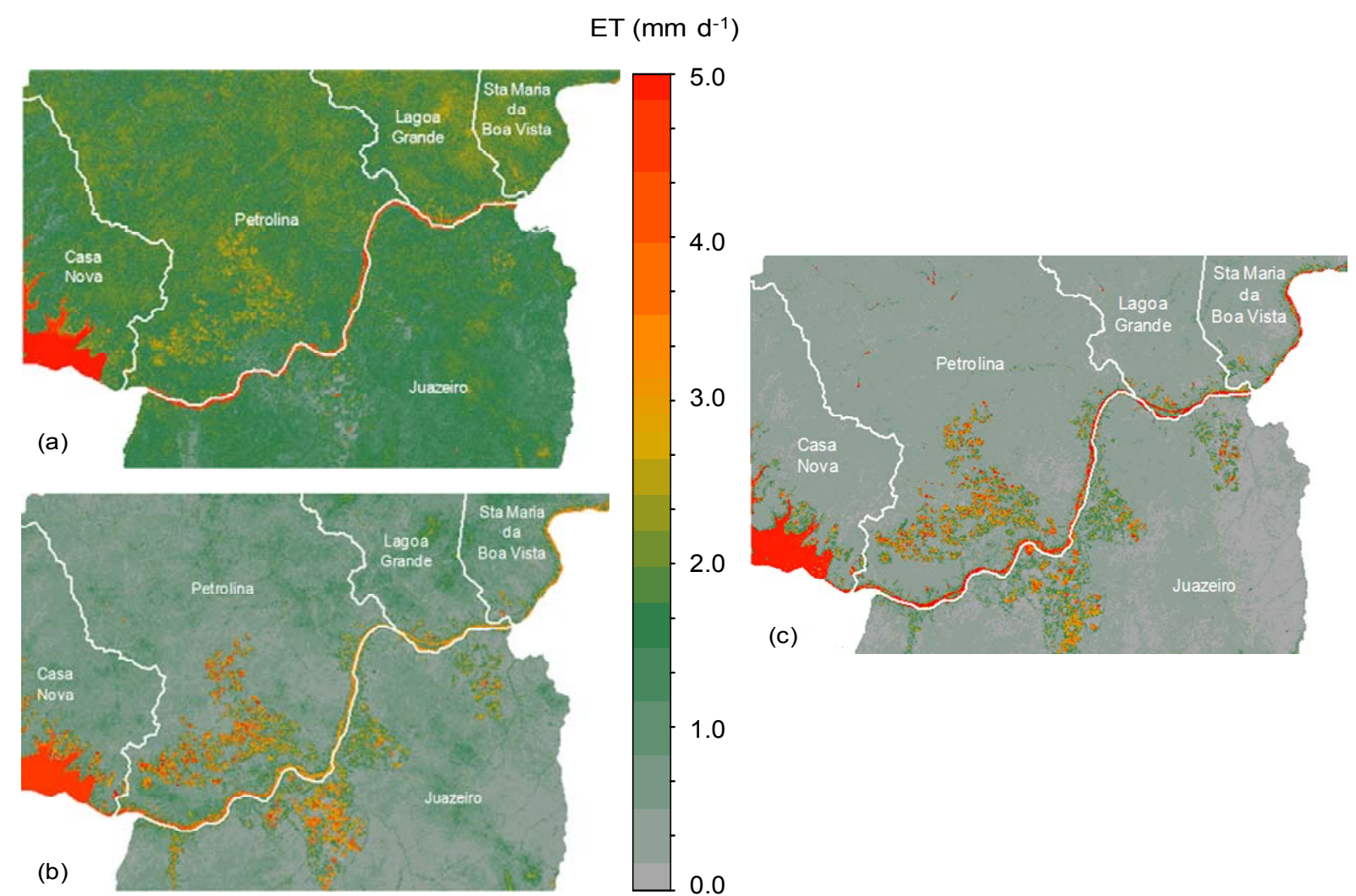

During the rainy period (Figure 11a), a large area comprised of the net of agro-meteorological stations presents similar values of ET, with the exception of water bodies. Intermediate values in natural vegetation occur just after the rainy season (Figure 11b), because antecedent precipitation during January to April provides sufficient water storage in the caatinga root zone still keeping the bushes wet and green, despite the quick rise of the atmospheric demand in the second half of the year. As a consequence of the higher portions of the available energy converted into $\mathrm{H}$, during the driest period of the year (Figure 11c), the natural vegetation presents low values of ET, while the irrigated fields show the highest ones. In general, irrigation intervals are short (daily irrigation), and the water supply is uniform, reducing the heat losses to the atmosphere. According to Figure 11, the effect of the soil moisture in the magnitude of the ET rates is strong. Pixels with values lower than $1.0 \mathrm{~mm} \mathrm{~d}^{-1}$ occur during the dry season representing the caatinga species. Values from 1.0 to $5.0 \mathrm{~mm} \mathrm{~d}^{-1}$ under the driest conditions of the year coincide with irrigated crops, being the highest values for table grapes [78].

The ET/ET 0 maps for the dry period of 2005 (October) and for the wet period of 2007 (January) were calibrated with field data of irrigated mango orchard and caatinga for the same DOY of 2006 to 
be used together with the image of July of this last year (Table 5). The average ET/ET 0 values from these three images, representative of different soil moisture conditions were multiplied by the grid of the total $\mathrm{ET}_{0}$ of 2006 giving the map of the annual ET (Figure 12).

Figure 12. Total annual actual evapotranspiration for 2006 for the region comprised of the net of agro-meteorological stations in the Low-Middle São Francisco river basin.

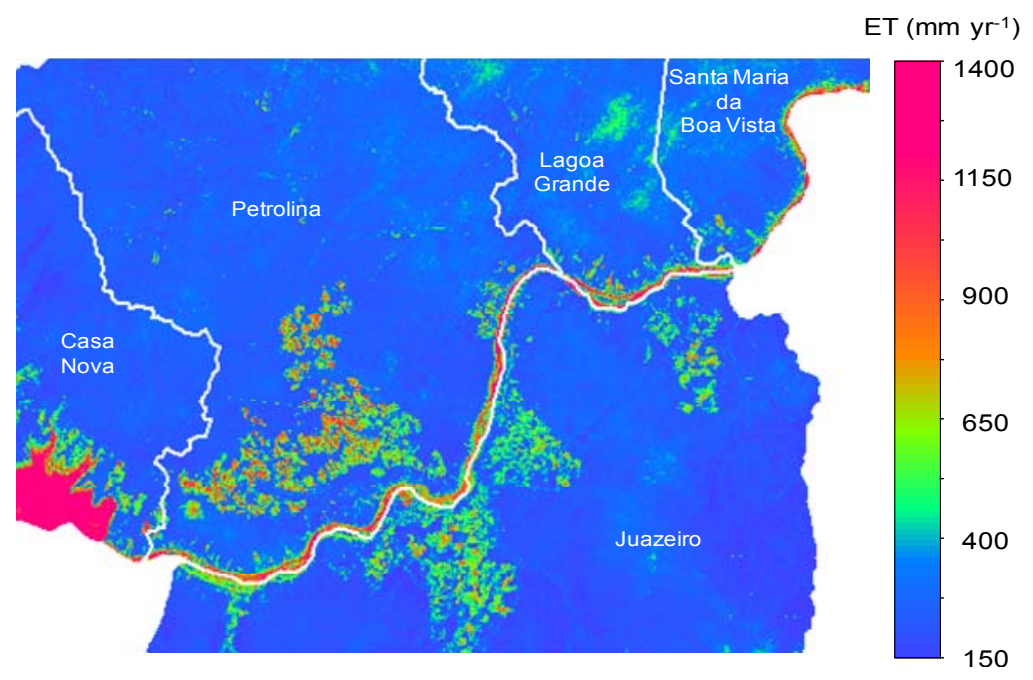

According to the location of the field experiments depicted in Figure 4, the highest accumulated regional ET values in 2006 (Figure 12) are for mango orchards, being around 500-1,300 mm $\mathrm{yr}^{-1}$. Vineyards presented lower values, ranging from 450 to $800 \mathrm{~mm} \mathrm{yr}^{-1}$, while in caatinga they were between 200 and $400 \mathrm{~mm} \mathrm{yr}^{-1}$. Considering that mango orchards are cultivated during the whole year and the cultivation of table grapes are restricted to the dry seasons, it can be concluded that irrigated mango orchards and vineyards consumed more water per area than caatinga by factors of 3 and 2 , respectively.

The classification of the Landsat images into irrigated areas and natural vegetation based on the $r_{s}$ values of Figure 7a allowed highlighting the incremental ET due to irrigation, in each growing region involved in the net of agro-meteorological stations. Summary statistics of land use and the regional ET for 2006 are shown in Table 6.

Table 6. Total $\left(\mathrm{A}_{\mathrm{T}}\right)$, irrigated $\left(\mathrm{A}_{\mathrm{I}}\right)$ and not irrigated $\left(\mathrm{AN}_{\mathrm{I}}\right)$ areas together with the annual actual evapotranspiration (ET) for irrigated crops (I) and natural vegetation (NV) in the growing regions comprised of the net of agro-meteorological stations in 2006.

\begin{tabular}{|c|c|c|c|c|c|}
\hline Growing regions & $\begin{array}{l}\mathbf{A}_{\mathrm{T}} \\
\text { (ha) }\end{array}$ & $\begin{array}{l}\mathbf{A}_{\text {I }} \\
\text { (ha) } \\
\end{array}$ & $\begin{array}{l}\mathbf{A}_{\mathrm{NI}} \\
\text { (ha) } \\
\end{array}$ & $\begin{array}{l}\mathbf{E T}_{\mathrm{I}} \\
\left(\mathrm{km}^{3} \mathrm{yr}^{-1}\right)\end{array}$ & $\begin{array}{l}\mathbf{E T}_{\mathrm{NV}} \\
\left(\mathrm{km}^{3} \mathrm{yr}^{-1}\right)\end{array}$ \\
\hline Petrolina-PE & 455,854 & 39,094 & 416,770 & 0.23 & 1.07 \\
\hline Lagoa Grande-PE & 185,219 & 4,363 & 180,856 & 0.02 & 0.54 \\
\hline Santa Maria da Boa Vista-PE & 297,780 & 4,793 & 292,987 & 0.03 & 0.88 \\
\hline Juazeiro-BA & 638,962 & 39,906 & 599,056 & 0.18 & 1.37 \\
\hline Casa Nova-BA & 965,751 & 7,831 & 965,751 & 0.04 & 2.30 \\
\hline
\end{tabular}


Petrolina and Juazeiro, in Pernambuco (PE) and Bahia (BA) states, respectively, are highlighted with the biggest irrigated areas. Even with the first growing region presenting a smaller value than that for the second, higher ET rates are verified which could be due to more irrigation water excess conditions in conjunction with greater evaporative demand. The growing region of Casa Nova-BA has the biggest area, with natural vegetation presenting the highest ET rates for this kind of vegetation, which is an indication of the best option for irrigation expansion in the Low-Middle São Francisco river basin, once adopting rational criteria for water resource management.

As the main irrigated crops for all the growing regions in the Low-Middle São Francisco river basin are vineyards and mango orchards, another summary of statistics for 2006 involving the growing regions are given in Table 7. The daily ET rates for grapes (GR) were taken from [5], while for mangoes (MG) these rates were from [13].

Table 7. Area of the main irrigated crops and annual actual evapotranspiration in the growing regions comprised of the net of agro-meteorological stations in 2006.

\begin{tabular}{lllll}
\hline Growing regions & $\begin{array}{l}\mathbf{A}_{\mathbf{G R}} \\
(\mathbf{h a})\end{array}$ & $\begin{array}{l}\mathbf{A}_{\mathbf{M G}} \\
\mathbf{( h a )}\end{array}$ & $\begin{array}{l}\mathbf{E T}_{\mathbf{G R}} \\
\mathbf{( m}^{\mathbf{3}} \mathbf{\mathbf { y r } ^ { - \mathbf { 1 } } \mathbf { ) }}\end{array}$ & $\begin{array}{l}\mathbf{E T}_{\mathbf{M G}} \\
\left.\mathbf{( m}^{\mathbf{3}} \mathbf{\mathbf { y r }} \mathbf{- 1}\right)\end{array}$ \\
\hline Petrolina-PE & 3,300 & 7,000 & $4,697,550$ & $4,336,200$ \\
Lagoa Grande- PE & 760 & 140 & $1,081,860$ & 998,640 \\
Santa Maria da Boa Vista-PE & 620 & 600 & 882,570 & 814,680 \\
Juazeiro-BA & 2,830 & 9,043 & $4,028,505$ & $3,718,620$ \\
Casa Nova-BA & 350 & 1,825 & 498,225 & 459,900 \\
\hline
\end{tabular}

Even though mangoes represent a bigger cropped area than for grapes, considering all growing regions comprised of the agro-meteorological stations and a continuous cultivation throughout the year for both crops, the annual mango orchards water consumption is a little lower than for vineyards. These cropped areas represent 19.4 and $8.2 \%$ of the total irrigated area, respectively, resulting in a total evaporative depletion of $0.22 \mathrm{~km}^{3} \mathrm{yr}^{-1}$. The incremental ET from irrigated crops in the Low Middle São Francisco river basin was reported as being $2.2 \mathrm{~mm} \mathrm{~d}^{-1}$ on average [78]. Considering all growing regions from Tables 6 and 7, the additional volume of water used was around $0.77 \mathrm{~mm} \mathrm{yr}^{-1}$ in 2006 . The latter volume represents the net depletion, the difference between diversion and return flow that is truly consumed and no longer available for downstream urban and environmental users.

Although the modeled seasonal and spatial patterns of ET are generally reasonable and consistent, for transferring the PM2 model to another Brazilian basin, probably local calibrations and validations are necessary for the coefficients of the equations relating ET/ET 0 with remote sensing parameters (Table 1). Further testing of the algorithm in different areas and climatic conditions with a net of agrometeorological stations and satellite images, is important for making the model applicable in the São Francisco centers of development.

\section{Conclusions}

Field radiation and energy balances in natural vegetation and irrigated crops, together with agrometeorological stations and Landsat images, were used to develop and validate two models based on the Penman-Monteith equation for regional evapotranspiration acquirement in the Low-Middle São 
Francisco river basin, Brazil. The images covered a period from 2001 to 2007. The first model (PM1) was based on the resistances to evapotranspiration, while the second uses the estimated ratio of the actual to the reference evapotranspiration (PM2). The PM1 model presented a regression coefficient of 0.79 and a root mean square error of $0.44 \mathrm{~mm} \mathrm{~d}^{-1}$, whereas for the best results of the PM2 model, the correspondent values were 0.89 and $0.34 \mathrm{~mm} \mathrm{~d}^{-1}$. The second model fitted more the line 1:1, explaining $89 \%$ of the variance and the first model explained $79 \%$ of the variance. The lower performance of PM1 model could be due to the fact that the weather data from the agro-meteorological stations are not representative of the dry microclimatic conditions of the natural vegetation.

Even with the PM1 model not being chosen for ET calculations, the equation for surface resistance was applied to infer the soil moisture conditions for a simplified vegetation classification. The maximum values of surface resistance were for natural vegetation - caatinga (average of $1,937 \mathrm{~s} \mathrm{~m}^{-1}$ ). Wine grape and mango orchard presented similar values around $130 \mathrm{~s} \mathrm{~m}^{-1}$, while table grape presented the lowest ones, averaging $74 \mathrm{~s} \mathrm{~m}^{-1}$. Petrolina and Juazeiro, in Pernambuco (PE) and Bahia (BA) states, respectively, were highlighted with the biggest irrigated areas.

The most important commercially irrigated crops in the semi-arid region of Brazil are vineyards and mango orchards, being the main responsible vegetation for the quick land use change, growing mainly in Petrolina-PE and Juazeiro-BA. In the case of Petrolina-PE, the larger increase is for vineyards, while in Juazeiro-BA the biggest area is for mango orchards. The highest increment for the first crop was verified between 2003 and 2004 in Petrolina-PE, when the cultivated area increased 151\%. In the case of mango orchards the most significant period was from 2005 to 2006 in Juazeiro-BA (129\%).

After having been identified as the best performance, the PM2 model was used to analyze the evapotranspiration from irrigated crops and natural vegetation. Considering the daily rates of the regional evapotranspiration, pixels with values lower than $1.0 \mathrm{~mm} \mathrm{~d} \mathrm{~m}^{-1}$ occurred outside the rainy season, representing the caatinga species. Values from 1.0 to $5.0 \mathrm{~mm} \mathrm{~d}^{-1}$ during the driest conditions of the year coincided with irrigated crops, being the highest values for table grapes. The highest accumulated ET values during 2006 were for mango orchards, being around 500-1,300 mm $\mathrm{yr}^{-1}$. Vineyards presented lower values, ranging from $450-800 \mathrm{~mm} \mathrm{yr}^{-1}$, while in the natural vegetation (caatinga) they were between 200 and $400 \mathrm{~mm} \mathrm{yr}^{-1}$. It could be concluded that irrigated mango orchards and vineyards consumed more water than caatinga by factors of 3 and 2, respectively.

Petrolina and Juazeiro in the semi-arid regions of Pernambuco and Bahia states presented the highest evapotranspiration rates, mainly as a consequence of land use change with the replacement of natural vegetation by vineyards and mango orchards. Analyzing land use together with the regional evapotranspiration for 2006 the regional evapotranspiration rates for these growing regions were 0.23 and $0.18 \mathrm{~km}^{3} \mathrm{yr}^{-1}$. Although the first growing region presented higher rates than the second, the irrigated area was lower: this could be a combined effect of irrigation water excess together with greater evaporative demand. The mango orchards and vineyard areas, representing 19.4 and $8.2 \%$ of the total irrigated area respectively, resulted in a total evaporative depletion of $0.22 \mathrm{~km}^{3} \mathrm{yr}^{-1}$ in the growing region covered by the agro-meteorological stations.

The separation of irrigated crops was possible by a simplified classification with logical functions applied to the surface resistance values. The incremental ET in the Low Middle São Francisco river basin was reported as being $2.2 \mathrm{~mm} \mathrm{~d}^{-1}$ on average [78]. Considering all growing regions analyzed, the additional volume of water used was around $0.77 \mathrm{~mm} \mathrm{yr}^{-1}$ in 2006 . The latter volume represents the 
net depletion, the difference between diversion and return flow that is truly consumed and no longer available for downstream urban and environmental users.

The results were rather encouraging given the complex mixture of the ecosystems in the semi-arid conditions, considering that only maps of NDVI, surface albedo and surface temperature together with interpolated data of reference evapotranspiration are necessary, without the need of crop classification, which is not straightforward in fruit crops. However, if the satellite does not have a thermal band, there is also the possibility of using grids of air temperature together with remote sensing parameters instead of surface temperature obtained from satellite measurements.

The actual condition of the evolution of the irrigated areas over the natural vegetation is an indication of the importance of having efficient tools for rational water resources management as water conflicts are imminent. With the use of remote sensing together with a net of agro-meteorological stations, one can make an historical evaluation of the evapotranspiration at the regional scale in the semi-arid areas of Brazil. The tools tested and presented here can be operationally tested and implemented to monitor the increase of irrigated agriculture, subsidizing ways to avoid environmental damage in hydrological basins with increasing land use change.

\section{Acknowledgements}

The research herein was supported by FACEPE (Science and Technology Foundation of Pernambuco state, Brazil) and Embrapa (Brazilian Agricultural Research Corporation). FACEPE is acknowledged for the financial support to the actual project on Water Productivity and Embrapa Semi-Arid for the instrumentation used during the field experiments.

\section{References and Notes}

1. Gleick, P.H. The World's Water 2000-2001: The Biennial Report on Freshwater Resources; Island Press: Washington, DC, USA, 2000.

2. Scott, C.A.; Bastiaanssen, W.G.M.; Ahmad, M.D. Mapping root zone soil moisture using remotely sensed optical imagery, J. Irr. Drain. Eng. ASCE 2003, 129, 326-335.

3. Inman-Bamber, N.G.; McGlinchey, M.G. Crop coefficients and water-use estimates for sugarcane based on long-term Bowen ratio energy balance measurements. Field Crops Res. 2003, 83, 125-138.

4. Lee, X.; Yu, Q.; Sun, X.; Liu, J., Min, Q.; Liu Y.; Zhang, X. Micrometeorological fluxes under the influence of regional and local advection: a revisit. Agr. Forest. Meteorol. 2004, 122, 11-124.

5. Teixeira, A.H. de C.; Bastiaanssen, W.G.M.; Bassoi, L.H. Crop water parameters of irrigated wine and table grapes to support water productivity analysis in Sao Francisco River basin, Brazil. Agr. Water Manag. 2007, 94, 31-42.

6. Cleverly, J.R.; Dahm, C.N.; Thibaut, J.R.; Gilroy, D.J.; Coonrod, J.E.A. Seasonal estimates of actual evapotranspiration from Tamarix ramosissima stands using three-dimensional eddy covariance. J. Arid Environ. 2002, 52, 181-197.

7. Humphreys, E.R.; Black, T.A.; Ethier, G.J.; Drewitt, G.B.; Spittlehouse, D.L.; Jork, E.M.; Nesic, Z.; Livingston, N.J. Annual and seasonal variability of sensible and latent heat fluxes above a coastal Douglas-fir forest, British Columbia, Canada. Agr. Forest. Meteorol. 2003, 115, 109-125. 
8. Lund, M.R.; Soegaard, H. Modelling of evaporation in a sparse millet using a two source model including sensible heat advection within the canopy. J. Hydrol. 2003, 280, 124-144.

9. Prueger, J.H.; Kustas, W.P.; Hipps, L.E.; Hatfield, J.L. Aerodynamic parameters and sensible heat flux estimates for a semi-arid ecosystem. J. Arid Environ. 2004, 57, 87-100.

10. Vilalolobos, F.J.; Testi, L.; Rizzalli, R.; Orgaz, F. Evapotranspiration and crop coefficients of irrigated garlic (Allium sativum L.) in a semi-arid climate. Agr. Water Manage. 2004, 64, 233-249.

11. Testi, L.; Villalobos, F.J.; Orgaz, F. Evapotranspiration of a young olive orchard in southern Spain. Agr. Forest. Meteorol. 2004, 121, 1-18.

12. Simmons, L.J.; Wang, J.; Sammis, T.W.; Miller, D.R. An evaluation of two inexpensive energy-balance techniques for measuring water use in flood-irrigated pecans (Carya illioinensis). Agr. Water Manage. 2007, 88, 181-191.

13. Teixeira, A.H.deC.; Bastiaanssen, W.G.M.; Moura, M.S.B.; Soares, J.M.; Ahmad, M.D.; Bos, M.G. Energy and water balance measurements for water productivity analysis in irrigated mango trees, Northeast Brazil. Agr. Forest. Meteorol. 2008a, 148, 1524-1537.

14. Teixeira, A.H.deC.; Bastiaanssen, W.G.M.; Ahmad, M.D.; Bos, M.G. Analysis of energy fluxes and vegetation-atmosphere parameters in irrigated and natural ecosystems of semi-arid Brazil. $J$. Hydrol. 2008b, 362, 110-127.

15. Meijninger, W.M.L.; De Bruin, H.A.R. The sensible heat fluxes over irrigated areas in Western Turkey determined with a large aperture scintillometer, J. Hydrol. 2000, 229, 42-49.

16. Meijninger, W.M.L.; Hartogensis, O.K.; Kohsiek, W.; Hoedjes, J.C.B.; Zuurbier, R.M.; De Bruin, H.A.R. Determination of area-averaged sensible heat fluxes with a large aperture scintillometer over a heterogeneous surface-Flevoland field experiment. Bound-Lay. Meteorol. 2002, 105, 37-62.

17. Wylie, B.; Johnson, D.; Laca, E.; Saliendra, N.; Gilmanov, T.; Reed, B.; Tieszen, L.; Bruce B.; Worstell, B. Calibration of remotely sensed, coarse resolution NDVI to CO2 fluxes in a sage-brush-steppe ecosystem. Remote. Sens. Environ. 2003, 85, 243-255.

18. Nagler, P.L.; Jetton, A.; Fleming, J.; Didan, K.; Glenn, E.; Erker, J.; Morino, K.; Milliken, J.; Gloss, S. Evapotranspiration in a cottonwood (Populus fremontii) restoration plantation estimated by sap flow and remote sensing methods. Agr. Forest. Meteorol. 2007, 144, 95-110.

19. Nagler, P.L.; Scott, R.L.; Westenburg, C.; Cleverly, J.R.; Glenn, E.P.; Huete, A.R. Evapotranspiration on western US rivers estimated using the Enhanced Vegetation Index from MODIS and data from eddy covariance and Bowen ratio flux towers. Remote. Sens. Environ. 2005, 97, 337- 351 .

20. Liu, J.; Chen, J.M.; Cihlar, J. Mapping evapotranspiration based on remote sensing: An application to Canada's landmass. Water. Resour. Res. 2003, 39, 1189, doi:10.1029/2002WR001680.

21. Boegh, E.; Thorsen, M.; Butts, M.B.; Hansena, S.; Christiansen, J.S.; Abrahamsen, P.; Hasager, C.B.; Jensen, N.O.; Van der Keur, P.; Refsgaard, J.C.; Schelde, K.; Soegaard, H.; Thomsen, A. Incorporating remote sensing data in physically based distributed agro-hydrological modelling. $J$. Hydrol. 2004, 287, 279-299.

22. van Niel, T.G.; McVicar, T.R. Current and potential uses of optical remote sensing in rice-based irrigation systems: a review. Aust. J. Agr. Res. 2004, 55, 155-185. 
23. Cleugh, H.A.; Leuning, R.; Mu, Q.; Running, S.W. Regional evaporation estimates from flux tower and MODIS satellite data. Remote. Sens. Environ. 2007, 106, 285-304.

24. Kimura, R.; Bai, L.; Fan, J.; Takayama, N.; Hinokidani, O. Evapotranspiration estimation over the river basin of the Loess Plateau of China based on remote sensing. J. Arid Environ. 2007, 68, 53-65.

25. Majumdar, T.J.; Brattacharyya, R.; Chattejee, S. On the utilization of ENVISAT AATSR data for geological/hydrological applications. Acta. Astron. 2007, 60, 899-905.

26. Akbari, M.; Toomanian, N.; Droogers, P.; Bastiaanssen. W.G.M.; Gieske, A. Monitoring irrigation performance in Esfahan, Iran, using NOAA satellite imagery. Agr. Water Manage. 2007, 88, 99-109.

27. Teixeira, A.H. de C.; Bastiaanssen, W.G.M.; Ahmad, M-ud-D; Bos, M. G. Reviewing SEBAL input parameters for assessing evapotranspiration and water productivity for the Low-Middle São Francisco River basin, Brazil Part A: Calibration and validation. Agr. Forest. Meteorol. 2009a, 149, 462-476.

28. Alexandrits, T.K.; Cherif, I.; Chemin, Y.; Silleous, G. N.; Stavrinos, E.; Zalidis, G. C. Integrated methodology for estimating water use in Mediterranean Agricultural Areas. Remote. Sens. 2009, $1,445-465$.

29. Hunsaker, D.J.; Pinter Jr.P. J.; Barnes, E.M.; Kimball, B.A. Estimating cotton evapotranspiration crop coefficients with a multispectral vegetation index. Irrigation. Sci. 2003, 22, 95-104.

30. Hunsaker, D. J.; Pinter, P.; Kimball, B. Wheat basal crop coefficients determined by normalized difference vegetation index. Irrigation. Sci. 2005, 24, 1-14.

31. Duchemin, J.; Hadria, R.; Er-Raki, S.; Boulet, G.; Maisongrande, P.; Chehbouni, A.; Escadafal, R.; Ezzahar, J.; Hoedjes, J.; Karroui, H.; Khabba, S.; Mougenot, B.; Olioso, A.; Rodriguez, J.-C.; Simonneaux, V. Monitoring wheat phenology and irrigation in Central Morocco: on the use of relationship between evapotranspiration, crops coefficients, leaf area index and remotely-sensed vegetation indices. Agr. Water Manage. 2006, 79, 1-27.

32. Tasumi, M.; Allen, R.G. Satellite-based ET mapping to assess variation in ET with timing of crop development. Agr. Water Manage. 2007, 88, 54-62.

33. Er-Raki, S.; Chehbouni, A.; Guemouria, N.; Duchemin, B.; Ezzahar, J.; Hadria, R. Combining FAO-56 model and ground-based remote sensing to estimate water consumptions of wheat crops in a semi-arid region. Agr. Water Manage. 2007, 87, 41-54.

34. Wang, K.; Li, Z.; Cribb, M. Estimation of evaporative fraction from a combination of day and night land surface temperatures and NDVI: A new method to determine the Priestly-Taylor parameter. Remote. Sens. Environ. 2007, 102, 293-305.

35. Kimura, R. Estimation of moisture availability over the Liudaogou river basin of the Loess Plateau using new indices with surface temperature. J. Arid Environ. 2007, 70, 237-252.

36. Sobrino, J.A.; Gómez, M.; Jiménez-Muñoz, J.C.; Olioso, A. Application of a simple algorithm to estimate daily evapotranspiration from NOAA-AVHRR images for the Iberian Peninsula. Remote. Sens. Environ. 2007, 110, 139-148.

37. Teixeira, A.H. de C.; Bastiaanssen, W.G.M.; Ahmad, M.D.; Bos, M. G. Reviewing SEBAL input parameters for assessing evapotranspiration and water productivity for the Low-Middle São Francisco River basin, Brazil Part B: Application to the large scale. Agr. Forest. Meteorol. 2009b, 149, 477-490. 
38. Bastiaansssen, W.G.M.; Menenti, M.; Feddes, R.A.; Roerink, G.J.; Holtslag, A.A.M. A remote sensing surface energy balance algorithm for land (SEBAL) 1. Formulation. J. Hydrol. 1998a, 212-213, 198-212.

39. Roerink, G.J.; Su, Z.; Menenti, M. S-SEBI: A simple remote sensing algorithm to estimate the surface energy balance. Phy. Chem. Earth 2000, 25, 147-157.

40. $\mathrm{Su}, \mathrm{Z}$. The Surface Energy Balance System (SEBS) for estimation of turbulent heat fluxes. Hydrol. Earth Syst. Sci. 2002, 6, 85-99.

41. Menenti, M.; Azzali, S.; D’Urso, G. Remote sensing, GIS and hydrological modelling for irrigation management. In Sustainability of Irrigated Agriculture; Pereira, L.S., Feddes, R.A., Gilley, J.R., Lesaffre, B., Eds.; Kluwer Academic Publishers: Dordrecht, The Netherlands, 1996; pp. 453-472.

42. Noordman, E.J.M., Moura, M.S.B., Teixeira, A.H.deC., Santos, M.A., Santos, M.G.L., Lopes, H.L. Crop classification for the Nilo Coelho scheme by using Landsat TM images. In Proceedings of Anais XI SBSR, Belo Horizonte, Brasil, April 2003; INPE: 205-210.

43. Bastiaanssen, W.G.M.; Pelgrum, H.; Soppe, R.W.O.; Allen, R.G.; Thoreson, B.P.; Teixeira, A.H. deC. Thermal infrared technology for local and regional scale irrigation analysis in horticultural systems. ISHS Acta Hort. 2008, 792, 33-46.

44. Kustas, W.P.; Norman, J.M. Evaluation of soil and vegetation heat flux predictions using a simple two-source model with radiometric temperatures for partial canopy cover. Agr. Forest Meteorol. 1999, 94, 13-29.

45. Norman, J.M.; Kustas, W.P.; Prueger, J.H.; Diak, G.R. Surface flux estimation using radiometric temperature: A dual-temperature-difference method to minimize measurement errors. Water Resour. Res. 2000, 36, 2263-2274.

46. Norman, J.M.; Anderson, M.C.; Kustas, W.P.; French, A.N.; Mecikalski, J.; Torn, R.; Diak, G.R.; Schmugge, T.J.; Tanner, B.C.W. Remote sensing of surface energy fluxes at 101-m pixel resolutions. Water Resour. Res. 2003, 39, SWC91-SWC917.

47. Kalma, J.D.; Jupp, D.L.B. Estimating evaporation from pasture using infrared thermometry: Evaluation of a one-layer resistance model. Agr. Forest Meteorol. 1990, 51, 223-246.

48. Allen, R.G.; Tasumi, M.; Morse, A.; Trezza, R.; Wright, J. L.; Bastiaanssen, W.G.M.; Kramber, W.; Lorite, I.; Robison, C.W. Satellite-based energy balance for mapping evapotranspiration with internalized calibration (METRIC)—Applications. J. Irr. Drain. Eng. ASCE 2007b, 133, 395-406.

49. Allen, R.G.; Tasumi M.; Morse, A.; Trezza, R; A Landsat-based energy balance and evapotranspiration model in Western US rights regulation and planning. Irr. Drain. System. 2005, 19, 251-268.

50. Moller, M.; Alchanatis, V.; Cohen, Y.; Meron, M.; Tsipris, J.; Naor, A.; Ostrovsky, V.; Sprintsin, M.; Cohen, S. Use of thermal and visible imagery for estimating crop water status of irrigated grapevine. J. Exp. Bot. 2005, 58, 827-838.

51. Naor, A. Irrigation scheduling and evaluation of tree water status in deciduous orchards. Hort. Rev. 2006, 32, 111-166.

52. Kustas, W.P.; Anderson, M.C.; French, A.N.; Vickers, D. Using a remote sensing field experiment to investigate flux-footprint relations and flux sampling distributions for tower and aircraft-based observations. Adv. Water. Res. 2006, 29, 355-368. 
53. Havstad, K.M.; Kustas, W.P.; Rango, A.; Ritchie, J.C.; Schmogge, T.J. Jornada experimental Range: A unique Arid Land Location for Experiments to Validate Satellite Systems. Remote. Sens. Environ. 2000, 74, 13-25.

54. Hemakumara, H.M.; Chandrapala, L.; Moene, A.F. Evapotranspiration fluxes over mixed vegetation areas measured from large aperture scintillometer. Agr. Water Manage. 2003, 58, 109-122.

55. Jia, L.; Su, Z.; den Hurk, B.; Menenti, M.; Moene, A.; De Bruin, H.A.R.; Yriassy. J.J.B.Y.; Ibanez, M.; Cuesta, A. Estimation of sensible heat flux using Surface Energy Balance System (SEBS) and ATSR measurements. Phy. Chem. Earth 2003, 28, 75-88.

56. Brunsell, N.A.; Gillies, R.R. Scale issues in land-atmosphere interactions: implications for remote sensing of the surface energy balance. Agr. Forest. Meteorol. 2003, 117, 203-221.

57. Pellenq, J.; Boulet, G. A methodology to test the pertinence of remote-sensing data assimilation into vegetation models for water and energy exchange at the land surface. Agronomie 2004, 24, 197-204.

58. Su, H.; McCabe, M.F.; Wood, E.F.; Su, Z.; Prueguer, J.H. Modeling evapotranspiration during SMACEX02: Comparing two approaches for local and regional scale prediction. J. Hydrometeor. 2005, 6, 910-922.

59. Leuning, R.; Cleugh, H.A.; Zegelin, S.J.; Hughes, D. Carbon and water fluxes over a temperate Eucalyptus forest and a tropical wet/dry savannah in Australia: measurements and comparison with MODIS remote sensing estimates. Agr. Forest. Meteorol. 2005, 129, 151-173.

60. Batra, N.; Islam, S.; Venturini, V.; Bisht, G.; Jiang, L. Estimation and comparison of evapotranspiration from MODIS and AVHRR sensors for clear sky days over the Southern Great Plains. Remote. Sens. Environ. 2006, 103, 1-15.

61. Allen, R.G.; Pereira, L.S.; Raes, D.; Smith, M. Crop Evapotranspiration: Guidelines for Computing Crop Water Requirements; Food and Agriculture Organization of the United Nations: Rome, Italy, 1998.

62. Garrat, J.R. The Atmosphere Boundary Layer; Cambridge University Press: Cambridge, UK, 1992; Cambridge atmospheric and space science series, p. 316.

63. Monteith, J.L. Principle of Environmental Physics; Edward Arnold publishers: London, UK, 1973; p. 236.

64. Penman, H.L. Natural evaporation from open water, bare soil and grass. In Proceedings of the Royal Society of London Series A, London, UK, 1948; Volume 193, pp. 120-145.

65. Monteith, J.L. Evaporation and the environment. The state and movement of water in living organisms. In Proceedings of Symposium of the Society of Experimental Biologists, Cambridge, UK, 1965; pp. 205-224.

66. Menenti, M.; Choudhury, B.J. Parameterization of land surface evaporation by means of location dependent potential evaporation and surface temperature range. In Exchange Processes at the Land Surface for a Range of Space and Time Scales; Bolle, H.-J., Feddes, R.A., Kalma, J.D., Eds.; IAHS Publ. No. 212, 1993; pp. 561-568.

67. Jarvis, P.G. The interpretation of the variations in leaf water potential and stomatal conductance found in canopies in the field. Phil. Trans. R. Soc. Lond. 1976, Ser. B 273, 593-610. 
68. Stewart, J.B. On the use of the Penman-Monteith equation for determining areal evapotranspiration. 3-2. In Estimation of Areal Evapotranspiration; Black, T.A., Spittlehouse, D.L., Novak, M.D., Price, D.T., Eds.; IAHS Publ. No. 177, International Association of Hydrological Sciences: England, UK, 1989.

69. Menenti, M.; Bastiaanssen, W.G.M.; Van Erick, D. Determination of hemispheric reflectance with thematic mapper data. Remote. Sens. Environ. 1989, 28, 327-337.

70. Troufleou, D.; Lhomme, J.-P.; Monteny, B.; Vidal, A. Sensible heat flux and radiometric surface temperature over sparse sahelian vegetation: is the $\mathrm{kB}^{-1}$ a relevant parameter? J. Hydrol. 1997, $189,815-838$.

71. Cleugh, H.A.; Dunin, F.X. modeling sensible heat fluxes from a wheat canopy: evaluation of resistance energy balance model J. Hydrol. 1995, 164, 127-152.

72. Kalma, J.D.; Jupp, D.L.B. Estimating evaporation from pasture using infrared thermometry: evaluation of one layer resistance model. Agr. Forest. Meteorol. 1990, 51, 223-246.

73. van der Griend, A.A.; Owe, M. Determination of microwave vegetation optical depth and single scattering albedo from large scale moisture and Nimbus/SMMR satellite observations. Int. J. Remote Sens. 1993, 14, 1975-1996.

74. Schmugge, T.J.; Kustas, W.P.; Titchie, J.C.; Jackson, T.J.; Rango, A. Remote sensing in hydrology. Adv. Water Res. 2002, 25, 1367-1385.

75. Suleiman, A.; Crago, R. Analytical land-atmosphere radiometer model. J. Appl. Meteorol. 2002, 41, 177-187.

76. Ortega-Farias, S.; Carrasco, M.; Olioso, A.; Acevedo, C.; Poblete, C.; Latent heat flux over Cabernet Sauvignon vineyard using the Shuttleworth and Wallace model. Irrig. Sci. 2007, 25, 161-170.

77. Businger, J.A.; Wyngaard, J.C.; Izumi, Y.; Bradley, E.F. Flux-profile relationships in the atmospheric surface layer. J. Atmos. Sci. 1971, 28, 189-191.

78. Teixeira, A.H. de C. Water productivity assessments from field to large scale: a case study in the Brazilian semi-arid region; LAP Lambert Academic Publishing: Saarbrücken, Germany, 2009.

79. Webb, E.K.; Pearmen, G.L.; Leuning, R. Correction of flux measurements for density effects due to heat and water vapour transfer. Q. J. Roy. Meteorol. Soc. 1980, 106, 85-100.

80. Tanner, B.D.; Swiatek, E.; Greene, J.P. Density fluctuations and use of the krypton hygrometer in surface flux measurements. In Proceedings of the National Conference on Irrigation Drainage Engineering, Park City, UT, USA, July 1993; pp. 21-23.

81. Moore, C.J. Frequency response corrections for eddy correlation systems. Bound.-Lay. Meteorol. 1986, 37, 17-35.

82. Wilson, K.; Goldstein, A.; Falge, E.; Aubinet, M.; Baldocchi, D.; Berbigier, P.; Bernhofer, C.; Ceulemans, R.; Dolman, H.; Field, C.; Grelle, A.; Ibrom, A.; Law, B.E.; Kowalski, A.; Meyers, T.; Moncrieff, J.; Monson, R.; Oechel, W.; Tenhunen , J.; Valentini , R.; Verma, S. Energy balance closure at Fluxnet sites. Agr. Forest. Meteorol. 2002, 113, 223-243.

83. Twine, T.E; Kustas, W.P.; Norman, J.M.; Cook, D.R.; Houser, P.R.; Meyers, T.P; Prueger, J.H.; Starks, P.J.; Wesely, M.L. Correcting eddy-covariance flux estimates over grassland. Agr. Forest. Meteorol. 2000, 103, 279-300. 
84. Paço, T.A.; Ferreira, M.I; Conceição, N. Peach orchard evapotranspiration in a sandy soil: Comparison between eddy covariance measurements and estimates by the FAO 56 approach. Agr. Water Manage. 2006, 85, 305-313.

85. Testi, L.; Orgaz F.; Villalobos F.J. Variations in bulk canopy conductance of an irrigated olive (Olea europaea L.) orchard. Env. Exp. Bot. 2006, 55, 15-28.

86. Paw U, K.T.; Baldocchi, D.D.; Meyers, T.P.; Wilson, K.B. Corrections of eddy covariance measurements incorporating both advective effects and density fluxes. Bound.-Lay. Meteorol. 2000, 97, 487-511.

87. Bastiaansssen, W.G.M. SEBAL-based sensible and latent heat fluxes in the irrigated Gediz Basin, Turkey. J. Hydrol. 2000, 229, 87-100.

88. Li, S.-G.; Eugster, W.; Asanuma, J; Kotani, A.; Davaa, G.; Oyunbaatar, D.; Sugita, M. Energy partitioning and its biophysical controls above a grazing steppe in central Mongolia. Agr. Forest. Meteorol. 1990, 137, 89-106.

89. Farah, H.O.; Bastiaanssen, W.G.M. Evaluation of the temporal variability of the evaporative fraction in a tropical watershed. Int. J. Appl. Earth Obs. Geoinf. 1997, 5, 129-140.

(C) 2010 by the authors; licensee MDPI, Basel, Switzerland. This article is an open-access article distributed under the terms and conditions of the Creative Commons Attribution license (http://creativecommons.org/licenses/by/3.0/). 